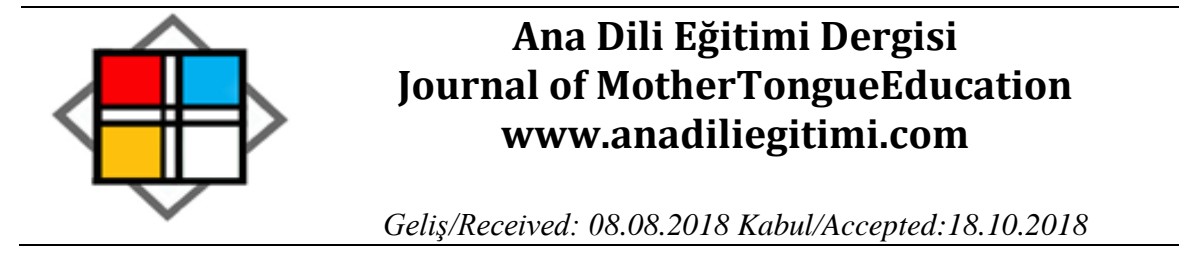

\title{
Bilişsel Farkındalık Stratejilerinin 7. Sınıf Öğrencilerinin Konuşma Becerilerini Geliştirmeye Etkisi* $^{*}$
}

\author{
Nurettin KARTALLIOĞLU**
}

\begin{abstract}
Öz
Bu araştırmanın amacı, hazırlıklı konuşmayla ilgili bilişsel farkındalık stratejilerinin 7. sınıf öğrencilerinin konuşma becerilerini geliştirmeye etkisini incelemektir. Bu amaca ulaşabilmek için; araştırma, nitel ve nicel araştırma yöntemlerinin birlikte kullanıldığı karışık desende yapılmıştır. Konuşmayla ilgili bilişsel farkındalık stratejileri ölçeği geliştirmek ve deneysel çalışma için nicel yöntem; hazırlıklı konuşma uygulamalarının yeterliliği ile ilgili veri elde etmek için ise nitel yöntem ve görüşme tekniği kullanılmıştır. Araştırma, Bolu'da 7. sınıfta öğrenim gören 22 deney ve 23 kontrol öğrencisi olmak üzere toplam 45 öğrenci ile yürütülmüştür. Araştırmada veri toplama aracı olarak araştırmacının geliştirdiği "Konuşma Stratejileri Bilişsel Farkındalık Ölçeği", "Hazırlıklı Konuşmayı Değerlendirme Ölçeği”, "Hazırlıklı Konuşmayı Öz Değerlendirme Ölçeği” ve açık uçlu sorulardan oluşan "Görüşme Formu" kullanılmıştır. Deney grubunda konuşma etkinlikleri, 12 hafta boyunca bilişsel farkındalık stratejilerine göre yapılmıştır. Kontrol grubunda ise ders kitaplarındaki etkinlikler çerçevesinde, geleneksel eğitim anlayışına göre konuşma etkinlikleri yürütülmüştür. Her iki gruptan 4 haftada bir hazırlıklı konuşma yapmaları ve bu konuşmayı sınıfta sunmaları istenmiştir. Araştırma sonunda, deney grubu öğrencilerinin hazırlıklı konuşma ön-son test puanları arasında anlamlı bir farkın olduğu tespit edilmiştir. Aynı şekilde deney grubu öğrencilerinin hazırlıklı konuşma ile ilgili bilişsel farkındalık düzeylerine ilişkin ön-son test puanları arasında son test puanları lehine anlamlı bir farkın olduğu tespit edilmiştir. Ancak kontrol grubu öğrencilerinin hazırlıklı konuşma ön-son test puanları arasında anlamlı bir farkın olmadığı belirlenmiştir. Aynı şekilde kontrol grubu öğrencilerinin hazırlıklı konuşma ile ilgili bilişsel farkındalık düzeylerine ilişkin ön-son test puanları arasında anlamlı bir farkın olmadığı tespit edilmiştir. Deney grubu öğrencileri, uygulanan hazırlıklı konuşma etkinliklerinin geleneksel eğitim etkinliklerine göre daha verimli ve eğitici olduğunu belirtmişlerdir.
\end{abstract}

Anahtar Kelimeler: Konuşma eğitimi, Hazırlıklı konuşma, Konuşma süreci, Bilişsel farkındalık, Strateji eğitimi.

\section{The Effect of Cognitive Awareness Strategies on the Improvement of the 7th Grade Students' Speaking Skills}

\begin{abstract}
The study aimed to find out the effect of cognitive awareness strategies for prepared speaking on speaking abilities of the 7th grade students. The study was designed as mixed method where qualitative and quantitative methods were both used. Quantitative method was used to develop a cognitive awareness scale for speaking and qualitative method and interview were used to collect data about the sufficiency of prepared speaking applications. The participants of the study were
\end{abstract}

\footnotetext{
* Bu çalışma "Bilişsel Farkındalık Stratejilerinin 7. Sınıf Öğrencilerinin Konuşma Becerilerini Geliştirmeye Etkisi" başlıklı doktora tezinden üretilmiştir.

** Öğr. Gör. Dr., Bolu Abant İzzet Baysal Üniversitesi, Türk Dili Bölümü, Bolu. E-posta: nurettinkartallioglu@gmail.com
} 
the 7th grade students studying in Bolu - 22 participants in the experimental group, 23 participants in the control group. For data collection, "Speaking Strategies Cognitive Awareness Scale" developed by the researcher, "Assessment Scale for Prepared Speaking", "Self-assessment Scale for Prepared Speaking" and an "Interview Form" including open-ended questions were used. Speaking activities were conducted for 12-week period considering cognitive awareness strategies in the experimental group. On the other hand, in the control group, traditional methods and the activities in the coursebook were followed. The students in both groups were asked to make a rehearsed speech and present it in the classroom once in every 4 weeks. At the end of the study, it was figured out that there was a significant difference between the pre-test and post -test scores of the students in the experimental group. Similarly, there was a significant difference between the pre and post-test scores of experimental group students about their cognitive awareness level for rehearsed speech in favor of post-test scores. However, the results showed that there was not a significant difference in the pre-test and post-test scores of the students in the control group. Likewise, there was no significant difference between the pre-post test scores of the control group students about their cognitive awareness for rehearsed speech. Experimental group students reported that prepared speaking activities were more effective and educative than traditional activities.

Keywords: Speaking education, Rehearsed speech, Speaking process, Cognitive awareness, Strategy training.

\section{Giriş}

Konuşma becerisi, zihinde karışık hâlde bulunan düşüncelerin hızlı bir şekilde düzenlenip dilin kodlarına çevrilmesini gerektiren karmaşık işlemlerden oluşmaktadır. Bununla beraber kişinin gündelik iletişim ihtiyacı büyük bir oranda konuşma vasıtasıyla sağlanmaktadır. Çünkü konuşma, yazmaya göre zihinsel olarak daha zor bir süreci gerektirse de (Yalçın, 2002: 98-99) sağladığı ekonomik ve pratik faydalardan dolayı yazmadan daha çok kullanılmaktadır.

Günlük hayatta yoğun bir şekilde kullanılan konuşma becerisinin, okuma ve yazmanın aksine, neredeyse doğuştan kazanılan bir beceri olması, okullarda eğitimine gerektiği kadar önem verilmemesi gibi bir sonucu doğurmuştur. Hâlbuki okuma ve yazma becerileri ne kadar eğitim gerektiriyorsa, konuşma becerisi de o kadar eğitim gerektirmektedir. Bilgi aktarımının büyük bir çoğunluğunun konuşma üzerinden yapıldığı düşünüldüğünde konuşma eğitiminin önemi kendiliğinden anlaşılır. Bunun için daha birinci sınıftan itibaren öğrencilere sağlıkı bir konuşma eğitimi verilmelidir. İyi bir konuşma eğitimi almayan öğrencilerin sonraki yıllarda konuşma becerilerinin gelişmesi de zorlaşmaktadır (Temizyürek, 2007). Yalçın (2002: 144) da, 4-16 yaşları arasındaki çocuklara etkili bir konuşma eğitimi verilmesi gerekliliğine dikkat çekerek ileri yaşlarda konuşma eğitiminin daha zor olacağını vurgulamıştır. Taşer (2012: 90) ise "Konuşma eğitimi insanın en yüce işlevlerini oluşturur, sinirsel ve zihinsel aygıtının verimli çalışmasını sağlar. Sonuç olarak, konuşma eğitimi ve alıştırmaları, gerçekte beynin gücünü geliştirir diyebiliriz." diyerek konuşma eğitiminin önemini ortaya koymuştur.

Okulda yapılacak etkili bir konuşma eğitimi kişinin sadece okul hayatını değil, okuldaki diğer derslerdeki başarısını ve dolayısıyla bütün hayatını etkileyecektir. Topçuoğlu Ünal ve Degeç (2012)'in yaptıkları araştırmada, araştırmaya katılan Türkçe öğretmenleri öğrencilerin konuşma becerilerinin gelişmemiş olması ve bunun sonucunda kendilerini ifade edememesinden kaynaklanan problemlerin 
sadece Türkçe derslerini değil bütün dersleri etkilediğini dile getirmiştir. Buna göre öğrencilerin konuşma becerisinin geliştirilmesi öğrencilerin bütün akademik hayatlarını etkilemektedir. Ayrıca aynı araştırmada, konuşma becerisi gelişmemiş öğrencilerin sosyal aktivitelere katılım oranlarının da çok düşük olduğu tespit edilmiştir. Görülüyor ki, konuşma becerisi öğrencilerin sadece akademik hayatını değil, aynı zamanda sosyal hayatını da olumlu ya da olumsuz bir şekilde etkilemektedir.

Konuşma eğitiminden beklenilen, kişinin hazırlıklı ve hazırlıksız olarak, bir kişi veya topluluk karşısında duygu, düşünce ve bilgilerini rahatça ifade etmesini sağlamaktır. Yalçın (2002), Temizyürek, Erdem ve Temizkan (2011), Özdemir (1999), Kaya (2011), Topçuoğlu ve Özden (2011) konuşmayı, hazırlıklı ve hazırlıksız (günlük) konuşma olarak ikiye ayırmışlardır. Konuşmanın türünü belirleyen konuşmanın yapılış biçimidir. Bazı konuşmalar hazırlık gerektirirken, bazı konuşmalar hazırlık gerektirmeyebilir.

Hazırlıklı konuşmaların, hazırlıksız konuşmalara oranla, dinleyicileri etkileme, yönlendirme ve harekete geçirme ihtimali daha fazladır. Hazırlıklı konuşmalar; konuşma öncesinde planlama ve hazırlık yapılması, konuşmanın birkaç kez prova edilmesi ve bu provalardan sonra düzeltilmesi gereken kısımların, eksikliklerin giderilerek tekrar düzenlenmesi bakımından hazırlıksız konuşmalara göre daha avantajlıdır (Sargın, 2006). Ama bu konuşmaların bir topluluk karşısında yapılması bazen konuşmacılar için aşırı heyecan, unutma, topluluk karşısında çekinme gibi birtakım olumsuzluklara sebep olabilmektedir. Bu sebeple öğrencilerin eğitim öğretim sırasında hazırlıklı konuşma yapmaya alıştırılmaları gerekmektedir.

Öğrencilerin bir konuya önceden hazırlanıp bunu arkadaşlarının önünde sunmalarının öğrencilere pek çok yararı vardır. Aldıkları bir konuyu disiplinli bir şekilde araştırmaları; çeşitli konu alanları ile görsel sunu, anlama ve anlatma becerilerini birlikte kullanmaları, hem hazırlıklı konuşmayı yapan hem de bu konuşmayı dinleyen öğrencilere önemli katkılar sağlayacaktır. Böylelikle öğrenciler takdir etme ve takdir edilme duygusunu yaşayacak ve bir işi başarabilmenin mutluluğunu hissedeceklerdir. Başarılı olduklarını gördükçe kendilerine olan güvenleri artacak ve derslerde daha aktif bir konuma geleceklerdir (Göçer, 2008: 14). Eğitimde öğrencilere seviyelerine uygun şekilde kendilerini geliştirebilecek, performanslarını gösterebilecek değişik görevlerin verilmesi, eğitim sürecini daha çekici bir hâle getirecektir. Böylelikle öğrencilerin derse karşı motivasyonları ve kendilerine olan güvenleri de artacaktır (Aydın ve Yılmaz, 2010). Ayrıca öğrenciler konuşmalarıyla kendi düşüncelerine güvenmeyi ve düşüncelerini geliştirmeyi öğrenirler (Güneş, 2014: 113).

Bir konu hakkında önceden hazırlanarak topluluk karşısında konuşma yapmak, çoğu kişinin istemediği bir durumdur. "Insanların büyük bölümü bir kişi veya bir topluluk karşısında konuşmaktan çekinir. Bu çekingenlik zaman zaman korkuya dönüşür. Amerika'da yapılan araştırmalar, Amerika 
halkının \%75'inin topluluk önünde konuşma korkusu olduğunu ortaya koymaktadır" (Arıkan, 2004; Akt. Doğan, 2009: 192). Öyle ki sözgelimi meşhurlardan Abraham Lincoln'un toplum önünde konuşmaktan çekindiği için ilk günlerde avuç içlerini tırnaklarıyla kanattığı, Gandi'nin heyecandan düşüp bayıldığı, Mark Twain'in ilk konuşmasında nabzının çok hızlı attığı bilinen gerçeklerdendir (Topçuoğlu ve Özden 2011: 211-212). Ülkemizde yapılan çalışmalarda bir topluluk önünde konuşma yapmanın zor bir iş olduğu ve büyük bir çoğunluğun bunu istemediği tespit edilmiştir. Göçer (2008), Yelok ve Sallabaş (2009), Akkaya (2012), Arslan (2012), Karakoç Öztürk ve Altuntaş (2012), Topçuoğlu Ünal ve Degeç (2012), tarafından yapılan araştırmalarda gerek ilkokul gerek üniversite öğrencilerinin gerekse de Türkçe öğretmeni adaylarının hazırlıklı bir konuşma yapmak istemedikleri ortaya çıkmıştır. Bunun nedenleri olarak ise, aşırı heyecan veya korku, ne söyleyeceğini bilememe, kendisi ile alay edilme, daha önce böyle bir konuşma yapmama gösterilmiştir. Bunların yanında öğrencilerde kavrama, yargılama, anlatım yetersizlikleri, dağınık konuşma, gereksiz söz söyleme, düşünce tekrarı, gereksiz beden hareketleri yapma gibi sorunlar da daha ilkokul ve ortaokul sıralarında karşımıza çıkan konuşma sorunlarındandır.

Başarılı bir hazırlıklı konuşmanın yapılabilmesi için konuşma öncesinde, konuşma sırasında ve konuşma sonrasında birtakım noktalara dikkat edilmesi gerekmektedir. Çünkü konuşma sırasında söyleneceklerin önceden zihinde sistemli bir şekilde planlanmaması, konuşma sırasında konuşmacıyı zor durumda bırakabilir. Bilgilerin nerede, nasıl ve ne zaman kullanılacağını bilmek çok önemlidir. Bu durum bireyin kendi düşünme süreçlerinin farkındalığı ile alakalıdır. Bu noktada da karşımıza bilişsel farkındalık kavramı çıkmaktadır.

\section{Bilişsel Farkındalık}

Kişinin öğrenme süreci hakkındaki farkındalığı, bilişsel farkındalıkla ilgilidir. Bilişsel farkındalık terimi 1970'li yılların başında Flavell tarafından bellek ötesi terimine bağlı olarak kullanılmıştır. Flavell (1979), terimi, bilişsel fenomen (olgu) hakkındaki bilgi ve biliş olarak tanımlayarak öğrenicilerin kendi bilgilerinin bilgisi olarak ifade etmiştir. Demir'e (2009: 1) göre "bilişsel farkındalık bir düşünme sistematiğidir. Öğrenmeyi öğrenme, dikkatini odaklama, yapılacak işi adım adım planlama, öğrenme sürecinin her aşamasını değerlendirme, gerekli düzeltme ve düzenlemeleri yapma işidir." Nasıl çalıştıklarının ve öğrendiklerinin farkında olan, verimli çalışma ve öğrenme süreci işleten öğrencilerin, bu süreçlerin farkında olmayan öğrencilere göre daha başarılı oldukları genel bir kabuldür (Eggen ve Kauchak, 2001; Akt. Candan, 2005: 327).

O'Malley ve Chamot (1990), bilişsel farkındalığa sahip olmayan öğrencilerin, öğrenmelerini planlayamadıklarını, öğrenme sürecini izleyemedikleri ve nasıl ilerleyeceklerini bilmediklerini belirtmiştir. Bilişsel farkındalık becerisi, bireylere öğrenmelerini planlamalarını, izlemelerini ve 
değerlendirmelerini sağlar, böylelikle öğrenme sürecinin bütün aşamalarında öğrenme sorumluluğunu alan öğrenci, öğrendiği bilgileri karşılaştığı sorunlara daha rahat uygulayarak daha başarılı olur (Schraw ve Dennison, 1994; Akt. Bağçeci, Döş, Sarıca, 2011: 553). Aynı şekilde bilişsel farkındalığa sahip olan bir konuşmacı, söyleyeceklerini önceden planlar, konuşma sırasında söylemek istediklerini tam olarak anlatıp anlatamadığını kontrol eder ve sözlerini buna göre düzenler. Konuşma sonrasında da konuşma konusu ile ilgili oluşturduğu amaçlara ulaşıp ulaşmadığını, beklentilerini karşılayıp karşılamadığını değerlendirir (Karatay, 2010: 460).

Bilişsel farkındalık stratejileri, bireylerin öğrenme sırasında daha bilinçli olmalarını sağlayarak öğrenmeyi olumlu yönde etkiler. Çünkü bu stratejiler, kişinin bir eylem üzerinde ve o eylemin nasıl daha iyi ve verimli yapılacağını düşünmesi demek olduğuna göre, konuşma becerisi bağlamında söylenecek olursa, konuşmanın da nasıl daha iyi yapılabileceği sorusunun cevabını vermektedir.

Bireylerin konuşma becerilerinin geliştirilmesi için çeşitli çalışmalar yapılmış ve yapılmaya devam edilmektedir. Bu çalışmalardaki ortak amaç bireylerin daha etkili ve güzel bir konuşma yapmalarını sağlamaktır. Bunu sağlamak için bazı araştırmalarda konuşma stratejileri önerilmektedir. Fakat yapılan araştırmalar incelendiğinde, [Nakatani (2005), Razmjoo ve Arkedani (2011), Xu (2012), Koşar ve Bedir (2014)] araştırmaların İngilizcenin yabancı dil olarak eğitimine yönelik olduğu görülmüştür. Ayrıca araştırmalarda genel olarak cinsiyet değişkeninin başarısı incelendiği belirlenmiştir.

Ülkemizde Yelok ve Sallabaş (2009), Aslan (2012), Topçuoğlu Ünal ve Degeç (2012)'in yaptıkları araştırmalara göre öğrencilerde bir topluluk karşısında hazırlıkı konuşma kaygılarının yüksek olduğu belirlenmiştir. Bu sorunun çözümüne yönelik olarak planlanan bu araştırma, çözüm olarak bilişsel farkındalık stratejilerini önermektedir. Çünkü bilişsel farkındalık stratejileri, kişinin bir eylemi planlama, uygulamaya koyma, kendini izleme ve değerlendirme becerilerini geliştirdiği bilinmektedir.

Temel eğitim Türkçe öğretim programlarından bugüne kadar konuşmayla ilgili yer verilen kazanım, yöntem ve tekniklerin, öğrencilerin hazırıklı konuşma becerilerini yeterli düzeyde geliştirmediği de bilinmektedir. Ders kitaplarında öğretmenlere sunulan etkinlikler de konuşma sürecini öğretecek nitelikte değildir. Hâlbuki eğitim sisteminde Türkçe eğitiminin amaçları düşünüldüğünde, iletişim kurma, problem çözme ve yaratıcı düşünmenin önemsendiği günümüzde öğretim araçlarındaki etkinliklerin daha tatmin edici olması beklenirdi.

Bu araştırmada, hazırlıkı konuşma eğitimi ile ilgili bilişsel farkındalık stratejilerinin 7. sınıf öğrencilerinin konuşma becerilerini geliştirmeye etkisi incelenmiştir. Araştırmanın problem cümlesi, “Konuşma ile ilgili öğrencilere kazandırılacak bilişsel farkındalık stratejileri, 7. sınıf öğrencilerinin konuşma becerilerini geliştirmede etkili midir?" şeklindedir. 


\section{Araştırmanın Alt Problemleri}

1. Deney grubu öğrencilerinin hazırlıklı konuşma ön-son test puanları arasında anlamlı bir fark var midır?

2. Kontrol grubu öğrencilerinin hazırlıklı konuşma ön-son test puanları arasında anlamlı bir fark var midır?

3. Deney ve kontrol grubu öğrencilerinin hazırlıklı konuşma son test puanları arasında anlamlı bir fark var midır?

4. Deney grubu öğrencilerinin hazırlıklı konuşma ile ilgili bilişsel farkındalık düzeylerine ilişkin ön testson test puanları arasında anlamlı bir fark var mıdır?

5. Kontrol grubu öğrencilerinin hazırlıklı konuşma ile ilgili bilişsel farkındalık düzeylerine ilişkin ön test -son test puanları arasında anlamlı bir fark var mıdır?

6. Deney ve kontrol grubu öğrencilerinin hazırlıklı konuşma ile ilgili bilişsel farkındalık düzeylerine ilişkin son test puanları arasında anlamlı bir fark var mıdır?

7. Öğrencilerin bilişsel farkındalık stratejilerine dayalı konuşma etkinlikleriyle ilgili görüşleri nelerdir?

\section{Yöntem}

\section{Araştırma Modeli}

Araştırma, nitel ve nicel yöntemlerin birlikte kullanıldığı karma yöntemle desenlenmiştir.

Araştırmanın nicel boyutunda bilişsel farkındalık stratejilerinin öğrencilerin konuşma becerilerine etkisini belirlemek için ön-son test kontrol gruplu tam deneysel model kullanılmıştır. Bu modelde, yansız atama yoluyla oluşturulmuş birbirine denk iki grup bulunur. Bu gruplardan biri deney grubunu, diğeri ise kontrol grubunu ifade etmektedir. Bu iki grupta da deney öncesi ve deney sonrası gerekli ölçmeler yapılır (Karasar, 2008: 97). Araştırma için 7. sınıfta okuyan birbirine denk (akademik başarı, öğrenci sayısı vb.) iki farklı sınıf seçilmiştir. Rastlantısal (random) atama yoluyla bu sınıflardan birisi deney, diğeri ise kontrol grubu olarak belirlenmiştir. Deney grubunda konuşma eğitimi dersi, 12 hafta boyunca bilişsel farkındalık stratejilerine dayalı konuşma eğitimine göre işlenmiştir. Kontrol grubunda ise, ders kitabındaki konuşma etkinliklerine göre ders işlenmiştir. Deney ve kontrol grubunun simgesel görünümü Tablo 1'de verilmiştir.

Tablo 1. Araştırmanın Deneysel Deseni

\begin{tabular}{clccc}
\hline Grup & Seçme Tipi & Ön Test & Deneysel Işlem & Son Test \\
\hline DG & R & O1 & Bilişsel farkındalık stratejilerine dayalı & O3 \\
KG & R & hazırlıklı konuşma etkinlikleri & 04 \\
\hline
\end{tabular}


Yukarıdaki tabloda, araştırmada DG deney grubunu, KG ise kontrol grubunu ifade etmektedir. Her iki gruba da uygulama öncesi "Konuşma Stratejileri Bilişsel Farkındalık Ölçeği” uygulanmıştır. O1 ve $\mathrm{O} 2$ ise uygulanan ön testi, $\mathrm{O} 3$ ve $\mathrm{O} 4$ ise deney grubuna 12 hafta boyunca uygulanan bilişsel farkındalık stratejileri hazırlıklı konuşma eğitimi sonunda uygulanan son testi göstermektedir.

Uygulamanın kullanışııı̆ını ve öğrencilere sağladığı katkıları belirlemek için nitel araştırma tekniklerinden görüşme tekniğinden yararlanılmıştır. Görüşme tekniğinin kullanılmasının sebebi, öğrencilere verilen konuşma stratejileri eğitimi, bu eğitimin öğrencilere neler kazandırdığı, öğrencilerin konuşmalarını planlamada, düzeltmede ve sunma süreçlerinde, zorlandıkları, kolay buldukları uygulama ve durumlarla ilgili görüşlerini derinlemesine belirlemektir. Bu araştırmada soruların önceden hazırlandığı ve görüşme sırasında esneklik sağlanması için yarı yapılandırılmış görüşme formu kullanılmıştır. Yarı yapılandırılmış görüşme, araştırmacının önceden hazırladığı soruların yanında açıklayıcı sorular sormasını da sağlar (Ayres, 2008; Akt.Topuzkanamış, 2014). Konuşma süreci ile ilgili öğrencilerin kolay buldukları veya zorlandıkları durumları belirlemek için hem açık uçlu sorulara hem de aynı durumu açıklatıcı sorulara yer verilmiştir. Böylelikle durumla ilgili tatmin edici veriler elde edilmeye çalışılmıştır.

\section{Çalışma Grubu}

Araştırmanın çalışma grubunu, Bolu ili merkez ilçede bulunan 50. Yıl Ortaokulunun 7. sınıf öğrencileri oluşturmaktadır. Çalışmada yedinci sınıf öğrencileri, 11-15 yaş arasındaki çocuklarda bilişsel farkındalık becerilerinin edinilmesinin daha kolay ve daha hızı olduğu için (Melanlıoğlu, 2011: 105) ayrıca araştırmanın çalışma grubunu oluşturan yedinci sınıf öğrencileri yıl içerisinde Türkiye çapında yapılacak herhangi bir merkezi değerlendirme ve yöneltme sınavına girmeyecekleri için tercih edilmiştir. Çalışma grubunun demografik özellikleri Tablo 2'de verilmiştir.

Tablo 2. Deney ve Kontrol Gruplarının Sınıf ve Cinsiyete Göre Dağılımı

\begin{tabular}{llll}
\hline Grup & Kız & Erkek & Toplam \\
\hline Deney grubu & 11 & 11 & $\mathbf{2 2}$ \\
Kontrol grubu & 12 & 11 & $\mathbf{2 3}$ \\
\hline Toplam & $\mathbf{2 3}$ & $\mathbf{2 2}$ & $\mathbf{4 5}$ \\
\hline
\end{tabular}

Çalışma grubu toplam 45 kişiden oluşmaktadır. Deney ve kontrol grubu öğrencilerinin cinsiyet açısından dağııımı benzerdir.

Çalışmaya katılacak öğrencilere uygulama öncesinde hazırlıklı konuşma ile ilgili hazır bulunuşluk düzeyleri arasında anlamlı bir farkın olup olmadığını belirlemek için serbest konulu bir hazırlıklı konuşma çalışması yapmaları istenmiş ve hazırııkı konuşma süreçlerindeki bilişsel farkındalık yeterlikleri “Hazırıklı Konuşmayı Değerlendirme Ölçeği” ile belirlenmiştir. Her iki gruptan elde edilen veriler ilişkisiz ölçümler t-testi ile sınanmış, bununla ilgili veriler Tablo 3'te verilmiştir. 
Tablo 3. Deney ve Kontrol Grubu Öğrencilerinin Ön Test Hazırlıklı Konuşma Puanlarına Ait ilişsisiz Ölçümler t Testi Sonuçları

\begin{tabular}{|c|c|c|c|c|c|c|c|}
\hline $\begin{array}{l}\text { Hazırlıklı konuşma } \\
\text { aşamaları }\end{array}$ & Grup & $\mathbf{N}$ & $\bar{X}$ & $\mathbf{S}$ & Sd & $\mathbf{T}$ & $\mathbf{p}$ \\
\hline \multirow{2}{*}{ 1.Hazırlık } & 1. Deney ön test & 22 & 2,89 & ,941 & \multirow{2}{*}{43} & \multirow{2}{*}{,940 } & \multirow{2}{*}{,352 } \\
\hline & 2. Kontrol ön test & 23 & 2,63 & ,885 & & & \\
\hline \multirow{2}{*}{ 2.Planlama } & 1. Deney ön test & 22 & 2,76 & 1,015 & \multirow{2}{*}{43} & \multirow{2}{*}{3,024} & \multirow{2}{*}{, $004^{*}$} \\
\hline & 2. Kontrol ön test & 23 & 1,98 & ,704 & & & \\
\hline \multirow{2}{*}{ 3. Düzeltme } & 1. Deney ön test & 22 & 2,18 & 1,332 & \multirow{2}{*}{43} & \multirow{2}{*}{1,141} & \multirow{2}{*}{,260 } \\
\hline & 2. Kontrol ön test & 23 & 1,78 & ,998 & & & \\
\hline \multirow{2}{*}{ 4.Sunum } & 1. Deney ön test & 22 & 3,24 & ,754 & \multirow{2}{*}{43} & \multirow{2}{*}{,843 } & \multirow{2}{*}{,404 } \\
\hline & 2. Kontrol ön test & 23 & 3,08 &, 535 & & & \\
\hline \multirow{2}{*}{ Toplam } & 1. Deney ön test & 22 & 2,77 & ,921 & \multirow{2}{*}{43} & \multirow{2}{*}{1,666} & \multirow{2}{*}{ 103 } \\
\hline & 2. Kontrol ön test & 23 & 2,37 & 679 & & & \\
\hline
\end{tabular}

$*$ p $<.0 .5$ anlamlı

Tablo 3'te deney ve kontrol grubu öğrencilerinin hazırlıklı konuşma düzeyleri ön test puan ortalamaları verilmiştir. Buna göre sadece planlama boyutunda grupların birbirine denk olmadığı, deney grubunun lehine anlamlı bir farkın olduğu; diğer alt boyutlarda ve hazırlıklı konuşma düzeylerinin genelinde deney ve kontrol grubunda yer alan öğrencilerin puanları arasında anlamlı bir farkın olmadığı belirlenmiştir.

Tablo 4. Deney ve Kontrol Grubunun Ön Test Hazırlıklı Konuşma Bilişsel Farkındalık Düzeylerine Ait Ilişkisiz Ölçümler t Testi Sonuçları

\begin{tabular}{lllllll}
\hline Grup & $\mathbf{N}$ & $\bar{X}$ & $\mathbf{S}$ & Sd & T & p \\
\hline 1. Deney ön test & 22 & 3,05 &, 435 & &, 962 \\
2. Kontrol ön test & 23 & 3,04 &, 506 & 43 &, 048 & \\
\hline
\end{tabular}

$* \mathrm{p}<0.5$ anlamlı

Tablo 4'te deney ve kontrol grubu öğrencilerinin hazırlıklı konuşma stratejilerine ilişkin bilişsel farkındalık düzeyleri ön test puan ortalamaları verilmiştir. Deney ve kontrol grubunda yer alan öğrencilerin hazırlıklı konuşma bilişsel farkındalık strateji düzeyleri arasında anlamlı bir farkın olmadığı görülmektedir.

\section{Veri Toplama Araçları}

Araştırma verilerini elde etmek için, "Konuşma Stratejileri Bilişsel Farkındalık Ölçeği", öğretmenin öğrencileri değerlendirmesi için “Hazırlıklı Konuşmayı Değerlendirme Ölçeği”, öğrencilerin kendilerini değerlenmeleri için “Hazırlıklı Konuşmayı Öz Değerlendirme Ölçeği” ve öğrencilerin eğitim süreciyle ilgili görüşlerini öğrenebilmek için de "Yarı Yapılandırılmış Görüşme Formu" kullanılmıştır. 


\section{Konuşma Stratejileri Bilişsel Farkındalık Ölçeği İle ilgili Bulgular ve Yorum}

Bu bölümde KSBFÖ ile ilgili yapılan güvenirlik ve geçerlik çalışmaları ile ilgili yapılan analizler ve elde edilen veriler hakkında bilgi verilmiştir.

\section{KSBFÖ’nün Güvenilirlik ve Geçerlilik Çalışması}

KSBFÖ’nün araştırmacı tarafından geliştirilmesi amacıyla ilgili alanyazın (Chamot, 1987; Oxford, 1990; Namlu, 2004; Karatay, 2009) taranarak 42 maddelik bir madde havuzu oluşturulmuştur. Psikometrik açıdan daha geniş ranja sahip olması için ölçeğin 5'li Likert tipinde olması kararlaştırılmıştır. Maddelerin karşısına "her zaman" (5), "genellikle" (4) "bazen" (3) "nadiren" (2) "hiçbir zaman" (1) şeklinde seçenekler konulmuş ve her bir seçeneğin gösterildiği gibi puanlanması istenmiştir.

Kapsam geçerliği ve maddelerin uygunluğunu belirleyebilmek için 3 alan uzmanından görüş alınarak bazı maddeler çıkarılmış ve 39 maddelik deneme formu Bolu ili Merkez ilçede bulunan Gazi Paşa Ortaokulunda 7. sınıfta eğitim gören 200 öğrenci üzerinde uygulanmıştır. Ölçeğin yapı geçerliği faktör analizi ile test edilmiştir. KMO değerinin 0,90 olduğu ve Bartlett Küresellik testinin anlamlı olduğu görülmektedir. Ölçeğin Hazırlık, Sunum ve Değerlendirme olmak üzere 3 alt faktörlü yapıda olduğu 14 maddeden oluştuğu sonucuna ulaşılmıştır. Ölçeğin 14 maddelik 3 alt faktörlü yapıda olduğu belirlenen ölçek, varyansın \%61,42'sini açıkladığı belirlenmiştir. Ölçeğin alt faktörlerine ilişkin güvenirliğin 0,76 ile 0,84 aralığında değiştiği ve geneline ilişkin güvenirliğin 0,90 olduğu sonucuna ulaşıımıştır. Ölçeğin doğrulayıcı faktör analizi aşamasında 7. sınıf düzeyinde öğrenim gören 218 öğrenci üzerinden kurulan 1. Düzey 3 Faktörlü DFA modelinin uyum indeks değerleri incelendiğinde (CMIN: 129.660, df: 68, CMIN/df: 1.907, GFI: .92, NFI: .93, TLI: .96, CFI: .97, RMSEA: 0.06) yapının doğrulandığı sonucuna ulaşılmıştır. Doğrulayıcı faktör analizinden elde edilen faktörler ve faktör yükleri Tablo 5 'te ve Grafik 1'de verilmiştir.

Tablo 5. Maddelerin Faktör Yükleri

\begin{tabular}{lllc}
\hline & & & Faktör Yükü \\
\hline $\mathrm{m} 1$ & $<---$ & F1 & .818 \\
$\mathrm{~m} 3$ & $<---$ & F1 & .759 \\
$\mathrm{~m} 4$ & $<---$ & F1 & .690 \\
$\mathrm{~m} 33$ & $<---$ & F2 & .756 \\
$\mathrm{~m} 34$ & $<---$ & F2 & .700 \\
$\mathrm{~m} 37$ & $<---$ & F2 & .847 \\
$\mathrm{~m} 38$ & $<---$ & F2 & .753 \\
$\mathrm{~m} 39$ & $<---$ & F2 & .695 \\
$\mathrm{~m} 17$ & $<---$ & F3 & .837 \\
$\mathrm{~m} 18$ & $<---$ & F3 & .826 \\
$\mathrm{~m} 21$ & $<---$ & F3 & .696 \\
$\mathrm{~m} 26$ & $<---$ & F3 & .701 \\
$\mathrm{~m} 27$ & $<---$ & F3 & .693 \\
$\mathrm{~m} 32$ & $<---$ & & .649 \\
\hline
\end{tabular}




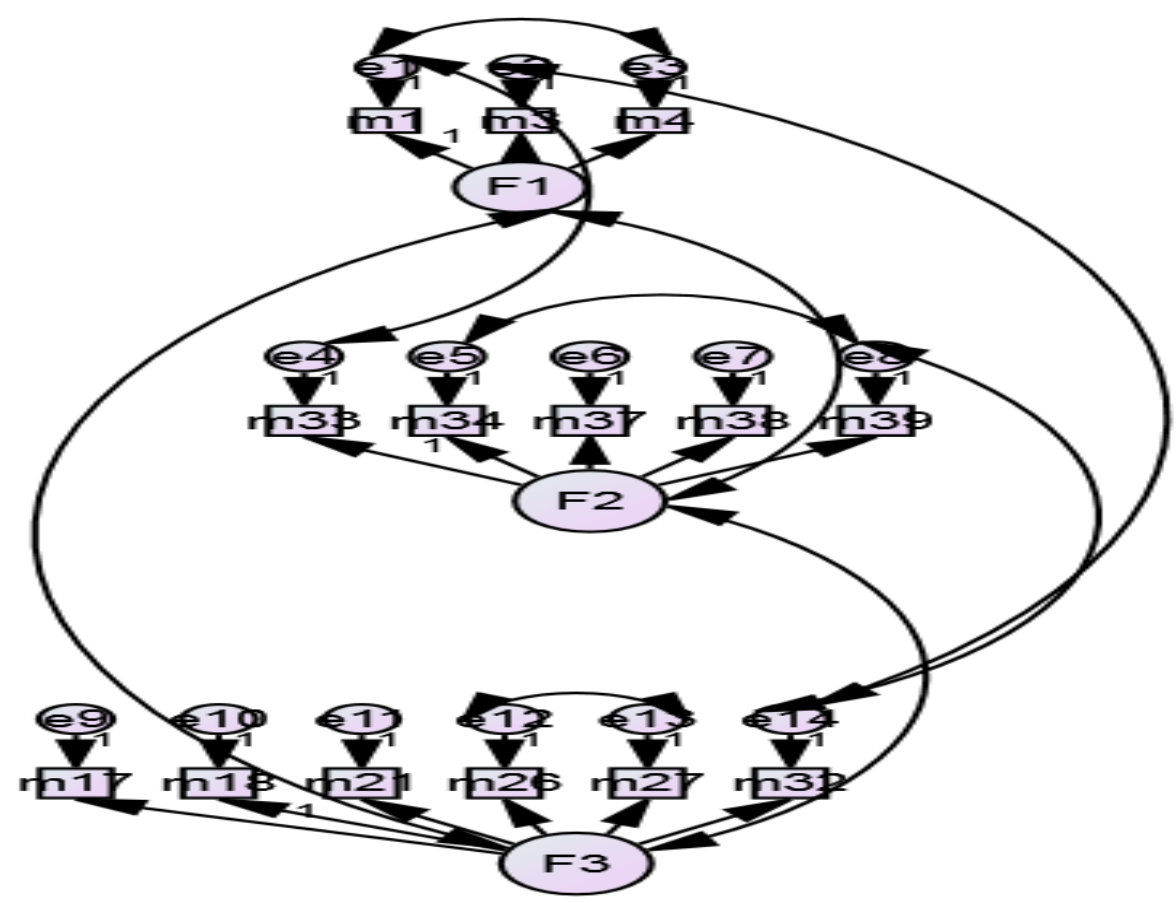

Grafik 1: Konuşma Stratejileri Bilişsel Farkındalık Ölçeği Doğrulayıcı Faktör Analizi

\section{KSBFÖ’yü Puanlama ve Değerlendirme}

KSBFÖ; konuşma öncesi, konuşma sırası ve konuşma sonrası olmak üzere üç boyuttan oluşmaktadır. KSBFÖ 1 [hiçbir zaman yapmam], 2 [nadiren yaparım], 3 [bazen yaparım], 4 [genellikle yaparım], 5 [her zaman yaparım] şeklinde puanlanan eşit aralıklı bir ölçektir. Ölçekte, öğrencilerin ölçekte yer alan maddeleri okuyup bu maddelerin tümünü kendi durumlarına uygun gelen şıkkı işaretlemeleri istenir. Öğrencilerin ölçeğe verdikleri puanlar; konuşma öncesi, konuşma sırası ve konuşma sonrası için ayrı ayrı toplanıp ilgili boyutun madde sayısına bölünerek öğrencilerin bu boyutlardaki düzeyleri ayrı ayrı tespit edilebildiği gibi; ölçeğin tamamına verilen puanlar toplanır, ölçekteki madde sayısına bölünmesiyle öğrencilerin hazırlıklı konuşma düzeyleri bütün olarak tespit edilebilir.

Oxford (1990: 291), öğrencilerin bilişsel farkındalık düzeylerinin değerlendirilmesinde; 3,5 puan ve yukarısını iyi; 2,5-3,4 puan arasını orta; 2,4 puan ve daha aşağısını zayıf olarak ifade etmiştir. Karatay (2009: 67) bu ölçütlerin alınan uzman görüşleri neticesinde Türkçe öğretiminde kullanılabilecek uygun ölçütler olduğunu belirtmiştir. Bunun neticesinde KSBFÖ’nün puanlanması ve değerlendirilmesinde bu ölçütlerin kullanılmasına karar verilmiştir.

\section{Hazırlıklı Konuşmayı Değerlendirme Ölçeği}

Hazırlıklı Konuşmayı Değerlendirme Ölçeği, öğretmenlerin öğrencilerin yapacakları hazırlıklı konuşmalarını değerlendirmeleri için oluşturulmuştur. Araştırmacı tarafından hazırlanan ölçek hazırlık, 
planlama, düzeltme ve sunum aşamalarını içeren 42 maddeden oluşmuştur. Ön uygulama çalışmasında aynı durumu ölçen 3 madde birbiriyle binişik olduğu için tekrar alan uzmanı 3 kişinin görüşü alınarak maddelerin tek bir maddede birleştirilmesine karar verilmiştir. Sonuç olarak, konuşma öncesi (hazırlık / planlama/ düzeltme) 14 madde, konuşma sırası (sunum) 18 madde, konuşma sonrası (değerlendirme) 7 madde olmak üzere 39 maddelik HKDÖ geliştirilmiştir.

HKDÖ; konuşma öncesi, konuşma sırası ve konuşma sonrası olmak üzere üç boyuttan oluşmaktadır. Hazırlıklı Konuşmayı Değerlendirme Ölçeği 1 [hiçbir zaman], 2 [nadiren], 3 [bazen], 4 [genellikle], 5 [her zaman] şeklinde puanlanan eşit aralıklı bir ölçektir. Buna göre aritmetik ortalaması 3'ün üzerindeki öğrencilerin hazırlıklı konuşma çalışmaları yeterli, altındakilerin yetersiz olduğu kabul edilmiştir.

\section{Hazırlıklı Konuşmayı Öz Değerlendirme Ölçeği}

Öğrenciler hazırıklı konuşma ile ilgili neler yapmaları gerektiği ile ilgili hem bilişsel farkındalık hem de süreci işletebilme becerilerini geliştirmek için ölçeğin maddeleri ben diline çevrilerek öz değerlendirme ölçeğine dönüştürülmüştür. Her hazırlıklı konuşma çalışmasında süreci takip ederek bunlara uygun hazırlık yapmaları istenmiştir.

\section{Hazırlıklı Konuşma İle İlgili Görüşme Formu}

Yarı yapılandırılmış görüşme, eğitim sürecinin değerlendirilmesi ve öğrenciler üzerindeki etkisini belirlemek amacıyla hazırlanmıştır. Araştırmacı tarafından hazırlanan 7 maddelik form, 3 alan uzmanından sözlü görüş alınarak 5 maddeye indirilmiştir. Böylelikle görüşme formuna son şekli verilmiştir, bununla ilgili sorulara bulgular kısmında yer verilmiştir.

\section{Uygulama Süreci}

Deney grubunda uygulanacak etkinlikler, haftada bir ders saati olacak şekilde, müfredata ve ders kitabına koşut hazırlanmıştır. Bununla eğitim öğretimin aksatılmadan sürdürülmesi sağlanmıştır. Deney grubunda hazırlıkı konuşma süreci ile ilgili hem strateji kullanma hem de özdenetim becerileri kazandırmak amacıyla öğrencilere 12 haftalık hazırlıklı konuşma etkinliği tasarlanmıştır.

Öğrencilerin hazırlıklı konuşma stratejileri ile ilgili özdenetim edinmelerini sağlamak amacıyla her konuşma etkinliğinde şu süreçler izlenmiştir: Birinci hafta konuşma konularını tespit etme ve konu ile ilgili araştırma yapmaları istenmiş, ikinci hafta, öğrencilerin araştırmalarını planlamaları sağlanmıştır. Üçüncü hafta, öğrencilerin yapmış oldukları planlarında gerekli kısımları düzeltmeleri istenmiş, dördüncü hafta ise öğrencilerden hazırladıkları konuşmalarını sunmaları istenmiştir. Araştırmada deney grubu öğrencileri bu süreci tekrar ederek üç kere hazırlıklı konuşma yapmıştır. 
Kontrol grubunda öğretmenin ders işleyiş sürecine hiçbir müdahalede bulunulmamıştır. Kontrol grubu öğrencileri ise ders kitaplarındaki etkinlikler çerçevesinde, geleneksel konuşma eğitimi anlayışına göre ders işleyişine devam etmiş ve dört haftada bir kere olmak üzere toplamda üç kez hazırlıklı konuşma yapmışlardır.

\section{Deney Grubunda Kullanılan Strateji}

Araştırmada konuşma öncesi, konuşma sırası ve konuşma sonrasında olmak üzere 17 basamaktan oluşan bir strateji eğitimi uygulanmıştır. Bu strateji, yapılan çalışmalar incelenerek öğrencilerin başarılı bir şekilde hazırlıklı konuşma yapabilmeleri için geliştirilmiştir. Strateji geliştirilirken öğrencilerin seviyeleri, amaç, süre göz önünde bulundurulmuştur.

Tablo 6. Deney Grubunda Verilen Stratejilerin Aşamalara Göre Dağılımı

\begin{tabular}{|c|c|}
\hline Aşama & Strateji \\
\hline \multirow{8}{*}{$\begin{array}{l}\text { A. Konuşma } \\
\text { Öncesi }\end{array}$} & 1. Konu Belirleme \\
\hline & 2. Amaç Belirleme \\
\hline & 3. Konuşma Konusuyla İlgili Bilgi Toplama ve Araştırma Yapma \\
\hline & 4. Konuşmayı Planlama \\
\hline & 5. Konuşma Konusunu Sınırlandırma \\
\hline & 6. Konuşma Yapmadan Önce Kendi Kendine Bir Sunu Yapma \\
\hline & 7. Sunumdan Sonra Düzeltilmesi Gereken Durumları Yeniden Düzenleme \\
\hline & 8. Konuşma Konusuyla İlgili Dinleyicilerden Gelebilecek Sorulara Hazırlık Yapma \\
\hline \multirow{6}{*}{$\begin{array}{l}\text { B. Konuşma } \\
\text { Sırası }\end{array}$} & 9. Konuya Etkili Bir Giriş Yapma \\
\hline & 10. Dinleyicilerin Anlayabileceği Bir Şekilde Konuşma Yapma \\
\hline & 11. Dinleyicilerin Dikkatini Dağıtacak Olumsuz Davranışlardan Kaçınma \\
\hline & 12. Konuşurken Konunun Dışına Çıkmaktan Kaçınma \\
\hline & 13. Konuyu Kısaca Özetleme \\
\hline & 14. Konuşmanın Sonunda Dinleyicilere Teşekkür Etme \\
\hline \multirow{3}{*}{$\begin{array}{l}\text { C. Konuşma } \\
\text { Sonrası }\end{array}$} & 15. Dinleyicilerden Gelen Eleştirileri Saygıyla Dinleme \\
\hline & 16. Dinleyicilerden Gelen Soruları İçtenlikle Cevaplama \\
\hline & 17. Konuşmanın Planlandığı Gibi Gerçekleşip Gerçekleşmediğini Değerlendirme \\
\hline
\end{tabular}

Yukarıda belirtilen strateji basamaklarından 1, 2, 3 ve 8. basamak konuşmanın araştırma aşaması; 4. ve 5. basamak konuşmanın planlanması; 6. ve 7. basamak konuşmanın düzeltilmesi; 9, 10, $11,12,13,14,15,16$ ve 17. basamaklar ise konuşmanın sunulması ile ilgili stratejilerdir. 12 haftalık eğitim boyunca öğrencilere araştırma, planlama, düzeltme ve sunum yapmaya yönelik etkinliklerle ders işlenmiştir.

\section{Verilerin Analizi}

Verilerin analizinde, HKDÖ’den alınan ön-son test puanları arasındaki farklılığın anlamlılığını belirleyebilmek için birinci, ikinci, dördüncü ve beşinci alt problemlerde ilişkili ölçümler t testi, üçüncü ve altıncı alt problemde ise ilişkisiz ölçümler t testi kullanılmıştır. Yedinci alt problemde ise içerik çözümlemesi kullanılmıştır. 


\section{Bulgular}

Araştırmanın birinci alt probleminde, "Deney grubu öğrencilerinin hazırlıklı konuşma ön-son test puanları arasında anlamlı bir fark var mıdır?" sorusuna yanıt aranmıştır.

Bu problemin çözümlenmesinde, deney grubu öğrencilerinin ön-son test hazırlıklı konuşma puanlarının aritmetik ortalamalarından yararlanılmıştır. Deney grubu öğrencilerinin ön-son test hazırlıklı konuşma düzeyleri arasında anlamlı bir farkın olup olmadığını test etmek için “ilişkili ölçümler t testi" kullanılmıştır. Bununla ilgili veriler Tablo 7'de verilmiştir.

Tablo 7. Deney Grubu Öğrencilerinin Ön - Son Test Hazırlıklı Konuşma Puanlarına Ait ilişskili Ölçümler $t$ Testi Sonuçları

\begin{tabular}{|c|c|c|c|c|c|c|c|}
\hline $\begin{array}{l}\text { Hazırlıklı } \\
\text { konuşma } \\
\text { aşamaları }\end{array}$ & Grup & $\mathbf{N}$ & $\bar{X}$ & $\mathbf{S}$ & Sd & $\mathbf{T}$ & $\mathbf{P}$ \\
\hline \multirow{2}{*}{ 1.Hazırlık } & 1. Deney ön test & 22 & 2,89 & ,941 & \multirow{2}{*}{42} & \multirow{2}{*}{$-6,493$} & \multirow{2}{*}{, $000^{*}$} \\
\hline & 2. Deney son test & 22 & 4,29 & ,368 & & & \\
\hline \multirow{2}{*}{ 2.Planlama } & 1. Deney ön test & 22 & 2,76 & 1,015 & \multirow{2}{*}{42} & \multirow{2}{*}{$-8,134$} & \multirow{2}{*}{, $000^{*}$} \\
\hline & 2. Deney son test & 22 & 4,57 & ,229 & & & \\
\hline \multirow{2}{*}{ 3. Düzeltme } & 1. Deney ön test & 22 & 2,18 & 1,332 & \multirow{2}{*}{42} & \multirow{2}{*}{$-7,772$} & \multirow{2}{*}{, $000^{*}$} \\
\hline & 2. Deney son test & 22 & 4,54 & ,509 & & & \\
\hline \multirow{2}{*}{ 4.Sunum } & 1. Deney ön test & 22 & 3,24 & 754 & \multirow{2}{*}{42} & \multirow{2}{*}{$-8,746$} & \multirow{2}{*}{, $000^{*}$} \\
\hline & 2. Deney son test & 22 & 4,70 & 207 & & & \\
\hline \multirow{2}{*}{ Toplam } & 1. Deney ön test & 22 & 2,77 & 921 & \multirow{2}{*}{42} & \multirow{2}{*}{$-8,649$} & \multirow{2}{*}{, $000^{*}$} \\
\hline & 2. Deney son test & 22 & 4,52 & ,240 & & & \\
\hline
\end{tabular}

$* p<.0 .5$ anlamlı

Tablo 7'de deney grubu öğrencilerinin hazırlıklı konuşma düzeyleri uygulama öncesi ve sonrasına ilişkin puan ortalamaları verilmiştir. Bilişsel farkındalık stratejilerine dayalı konuşma eğitimi etkinlikleri uygulamaları öncesinde deney grubunun ön test hazırlıklı konuşma düzeyleri aritmetik ortalamaları $(2,77)$, son test aritmetik ortalamalarına $(4,52)$ göre daha düşüktür. Deney grubu öğrencilerinin ön-son test hazırlıklı konuşma düzeyleri arasında anlamlı bir farkın olup olmadığını belirlemek için puan ortalamaları, ilişkili ölçümler t testi ile sınanmıştır.

Deney grubu öğrencilerinin ön-son test hazırlıklı konuşma puan ortalamaları arasında anlamlı bir farkın olduğu [t(42) $=-8.649, p<.000]$ belirlenmiştir. Bu durum, 7. sınıf öğrencilerinin hazırlıklı konuşma düzeylerini artırmaya yönelik yapılan bilişsel farkındalık stratejilerine dayalı konuşma eğitimi etkinliklerinin hazırlıklı konuşma becerisini geliştirdiğini göstermektedir.

Hazırlıklı konuşmanın alt boyutları ile ilgili durum incelendiğinde, tablonun birinci satırında görüldüğü gibi, öğrencilerin konuşmanın hazırlık aşaması ile ilgili son test puan ortalamaları $(4,29)$, ön testteki puan ortalamalarına $(2,89)$ göre daha yüksektir. Öğrencilerin hazırlık sürecine ilişkin konuşma 
düzeyi son testteki puan ortalamalarının lehine, anlamlı fark [t(42)=-6.493, $\mathrm{p}<.000]$ göstermiştir. Bilişsel farkındalık stratejilerine dayalı konuşma eğitimi etkinlikleri öğrencilerin konuşmaya hazırlık yapma düzeylerini geliştirdiği söylenebilir.

Tablonun ikinci satırında planlama ile ilgili veriler vardır. Buna göre, öğrencilerin konuşmanın planlama aşaması ile ilgili son test puan ortalamaları $(4,57)$, ön testteki puan ortalamalarına $(2,76)$ göre daha yüksektir. Öğrencilerin planlama sürecine ilişkin konuşma düzeyi son testteki puan ortalamalarının lehine, anlamlı fark [t(42)=-8.134, $\mathrm{p}<.000]$ göstermiştir. Bilişsel farkındalık stratejilerine dayalı konuşma eğitimi etkinlikleri öğrencilerin konuşmayı planlama düzeylerini geliştirdiği söylenebilir.

Tablonun üçüncü satırı incelendiğinde öğrencilerin konuşmayı düzeltme aşaması ile ilgili son test puan ortalamaları $(4,54)$, ön testteki puan ortalamalarına $(2,18)$ göre daha yüksektir. Öğrencilerin planlama sürecine ilişkin konuşma düzeyi son testteki puan ortalamalarının lehine, anlamlı fark [t(42)=7.772, p <.000] göstermiştir. Bilişsel farkındalık stratejilerine dayalı konuşma eğitimi etkinlikleri öğrencilerin konuşmayı düzeltme düzeylerini geliştirdiği söylenebilir.

Aynı şekilde, tablonun dördüncü satırı incelendiğinde öğrencilerin konuşmanın sunum aşaması ile ilgili son test puan ortalamaları $(4,70)$, ön testteki puan ortalamalarına $(3,24)$ göre daha yüksektir. Öğrencilerin sunum sürecine ilişkin konuşma düzeyi son testteki puan ortalamalarının lehine, anlamlı fark $[t(42)=-8.746, p<.000]$ göstermiştir. Bilişsel farkındalık stratejilerine dayalı konuşma eğitimi etkinlikleri öğrencilerin konuşmanın sunum aşaması ile ilgili becerilerini de geliştirdiği belirlenmiştir.

Araştırmanın ikinci alt probleminde, "Kontrol grubu öğrencilerinin hazırlıklı konuşma ön-son test puanları arasında anlamlı bir fark var mıdır?" sorusuna yanıt aranmıştır.

Bu problemin çözümlenmesinde, kontrol grubu öğrencilerinin ön-son test hazırlıklı konuşma puanlarının aritmetik ortalamalarından yararlanılmıştır. Kontrol grubu öğrencilerinin ön-son test hazırlıklı konuşma düzeyleri arasında anlamlı bir farkın olup olmadığını test etmek için “ilişkili ölçümler t testi" kullanılmıştır. Bununla ilgili veriler Tablo 8'de verilmiştir.

Tablo 8. Kontrol Grubu Öğrencilerinin Ön - Son Test Hazırlıklı Konuşma Puanlarına Ait Ilişkili Ölçümler $t$ Testi Sonuçları

\begin{tabular}{|c|c|c|c|c|c|c|c|}
\hline $\begin{array}{l}\text { Hazırlıklı } \\
\text { konuşma } \\
\text { aşamaları }\end{array}$ & Grup & $\mathbf{N}$ & $\bar{X}$ & S & Sd & $\mathbf{T}$ & $\mathbf{P}$ \\
\hline \multirow{2}{*}{ 1.Hazırlık } & 1. Kontrol ön test & 23 & 2,63 & ,885 & \multirow{2}{*}{44} & \multirow{2}{*}{2,219} & \multirow{2}{*}{,032* } \\
\hline & 2. Kontrol son test & 23 & 2,16 & 495 & & & \\
\hline \multirow{2}{*}{ 2.Planlama } & 1. Kontrol ön test & 23 & 1,98 & 704 & \multirow{2}{*}{44} & \multirow{2}{*}{071} & \multirow{2}{*}{944} \\
\hline & 2. Kontrol son test & 23 & 1,96 & 461 & & & \\
\hline \multirow{2}{*}{ 3. Düzeltme } & 1. Kontrol ön test & 23 & 1,78 & 998 & \multirow{2}{*}{44} & \multirow{2}{*}{ 299 } & \multirow{2}{*}{,766 } \\
\hline & 2. Kontrol son test & 23 & 1,69 & 973 & & & \\
\hline 4.Sunum & 1. Kontrol ön test & 23 & 3,08 & ,535 & 44 & 1,056 & 297 \\
\hline
\end{tabular}


Bilişsel Farkındalık Stratejilerinin 7. Sınıf Öğrencilerinin Konuşma Becerilerini Geliştirmeye Etkisi

\begin{tabular}{llllllll} 
& 2. Kontrol son test & 23 & 2,93 &, 443 & & & \\
\multirow{3}{*}{ Toplam } & 1. Kontrol ön test & 23 & 2,37 &, 679 & 403 & 1,041 \\
\hline & 2. Kontrol son test & 23 & 2,19 &, 478 & & & ,303 \\
\hline
\end{tabular}

Tablo 8'de kontrol grubu öğrencilerinin hazırlıklı konuşma düzeyleri uygulama öncesi ve sonrasına ilişkin puan ortalamaları verilmiştir. Kontrol grubunun konuşma eğitimi etkinlikleri uygulamaları öncesinde ön test hazırlıklı konuşma düzeyleri aritmetik ortalamaları 2,37 iken son test aritmetik ortalamaları 2,19'dur. Kontrol grubu öğrencilerinin ön - son test hazırlıklı konuşma düzeyleri arasında anlamlı bir farkın olup olmadığını belirlemek için puan ortalamaları, ilişkili ölçümler t testi ile sınanmıştır.

Kontrol grubu öğrencilerinin ön test ile son test hazırlıklı konuşma puan ortalamaları arasında anlamlı bir farkın olmadığı $[t(44)=1.041, p>$.303] belirlenmiştir. Bu durum, 7. sınıf öğrencilerinin hazırlıklı konuşma düzeylerini artırmaya yönelik yapılan konuşma eğitimi etkinliklerinin hazırlıkı konuşma becerisini geliştirmediğini göstermektedir.

Ayrıca tablonun birinci satırında görüldüğü gibi, öğrencilerin konuşmanın hazırlık aşaması ile ilgili son test puan ortalamaları $(2,16)$, ön testteki puan ortalamalarına $(2,63)$ göre daha düşüktür. Öğrencilerin hazırlık sürecine ilişkin konuşma düzeyi ön testteki puan ortalamalarının lehine, anlamlı fark $[t(44)=2.219, p<.032]$ göstermiştir. Konuşma eğitimi etkinlikleri öğrencilerin konuşmaya hazırlık yapma düzeylerini geliştirmediği hatta anlamlı bir şekilde gerilettiği söylenebilir.

Tablonun ikinci, üçüncü ve dördüncü satırlarında görüldüğü gibi, öğrencilerin konuşmanın planlama, düzeltme ve sunum aşamaları ile ilgili ön-son test puan ortalamaları arasında anlamlı bir farkın olmadığı görülmektedir. Geleneksel konuşma eğitimi etkinliklerinin, öğrencilerin konuşmayı planlama, düzeltme ve sunum aşamaları ile ilgili becerilerini geliştirmediği görülmektedir.

Bu durum, geleneksel eğitim anlayışıyla oluşturulan konuşma etkinliklerinin gözden geçirilmesi gerektiğini ortaya koymaktadır. Öğrencilerin öğrenme sürecine aktif olarak katılmalarını ve kendi öğrenmelerinden sorumlu bireyler olmalarını sağlamak eğitim sisteminin görevidir. Bu bakımdan öğrencilere yol göstererek, öğrencilerin kendi öğrenmelerini planlamalarını, düzenlemelerini ve değerlendirmelerini sağlayacak etkinliklerin yapılması gerekmektedir.

Araştırmanın üçüncü alt probleminde, "Deney ve kontrol grubu öğrencilerinin hazırlıklı konuşma son test puanları arasında anlamlı bir fark var mıdır?" sorusuna yanıt aranmıştır.

Bu problemin çözümlenmesinde, deney ve kontrol grubu öğrencilerinin son test hazırlıklı konuşma puanlarının aritmetik ortalamalarından yararlanılmıştır. Deney ve kontrol grubu 
öğrencilerinin son test hazırlıklı konuşma düzeyleri arasında anlamlı bir farkın olup olmadığını test etmek için “ilişkisiz ölçümler t testi” kullanılmıştır. Bununla ilgili veriler Tablo 9'da verilmiştir.

Tablo 9. Deney ve Kontrol Grubu Öğrencilerinin Son Test Hazırlıkı Konuşma Puanlarına Ait ilişkisiz Ölçümler t Testi Sonuçları

\begin{tabular}{llllllll}
\hline $\begin{array}{l}\text { Hazırlıklı } \\
\text { konuşma } \\
\text { aşamaları }\end{array}$ & Grup & N & $\bar{X}$ & S & Sd & T & P \\
\hline 1. Hazırlık & 1. Deney son test & 22 & 4,29 &, 368 & 43 & 16,253 &, $000^{*}$ \\
& 2. Kontrol son test & 23 & 2,16 &, 495 & & & \\
2. Planlama & 1. Deney son test & 22 & 4,57 &, 229 & 43 & 23,774 &, $000^{*}$ \\
& 2. Kontrol son test & 23 & 1,96 &, 461 & & & \\
3. Düzeltme & 1. Deney son test & 22 & 4,54 &, 509 & 43 & 12,214 &, $000^{*}$ \\
& 2. Kontrol son test & 23 & 1,69 &, 973 & & & \\
4. Sunum & 1. Deney son test & 22 & 4,70 &, 207 & 43 & 17,065 &, $000^{*}$ \\
& 2. Kontrol son test & 23 & 2,93 &, 443 & & & \\
Toplam & 1. Deney son test & 22 & 4,52 &, 240 & & & \\
& 2. Kontrol son test & 23 & 2,19 &, 478 & 43 & 20,570 &, $000^{*}$ \\
\hline
\end{tabular}

$* p<, 05$ anlamlı

Tablo 9'da deney ve kontrol grubu öğrencilerinin hazırlıklı konuşma düzeyleri son test puan ortalamaları verilmiştir. Bilişsel farkındalık stratejilerine dayalı konuşma eğitimi etkinlikleri uygulamaları sonrasında deney grubunun son test hazırlıkı konuşma düzeyleri aritmetik ortalamaları 4,52 iken geleneksel konuşma eğitimi etkinlikleri uygulamaları sonrasında kontrol grubunun son test hazırlıklı konuşma düzeyleri aritmetik ortalamaları 2,19'dur. Deney ile kontrol grubu öğrencilerinin son test hazırlıklı konuşma düzeyleri arasında anlamlı bir farkın olup olmadığını belirlemek için puan ortalamaları, ilişkisiz ölçümler t testi ile sınanmıştır.

Deney grubu ile kontrol grubu öğrencilerinin son test hazırlıklı konuşma puan ortalamaları arasında anlamlı bir farkın olduğu $[\mathrm{t}(43)=-8.649, \mathrm{p}<.000$ ] belirlenmiştir. Bu durum, 7. sınıf öğrencilerinin hazırlıklı konuşma düzeylerini artırmaya yönelik yapılan bilişsel farkındalık stratejilerine dayalı konuşma eğitimi etkinliklerinin hazırlıklı konuşma becerisini geliştirdiğini göstermektedir.

Ayrıca tablonun birinci satırında görüldüğü gibi, deney grubu öğrencilerinin konuşmanın hazırlık aşaması ile ilgili son test puan ortalamaları $(4,29)$, kontrol grubu öğrencilerinin son test puan ortalamalarına $(2,16)$ göre daha yüksektir. Konuşmanın hazırlık aşaması ile ilgili öğrencilerin son testteki puan ortalamaları deney grubunun lehine, anlamlı fark $[t(43)=16.253, p<.000]$ göstermektedir. Bilişsel farkındalık stratejilerine dayalı konuşma eğitimi etkinlikleri öğrencilerin konuşmaya hazırık yapma düzeylerini, kontrol grubunda uygulanan konuşma eğitimi etkinliklerine göre daha fazla geliştirdiği belirlenmiştir. 
Tablonun ikinci satırında görüldüğü gibi, deney grubu öğrencilerinin konuşmanın planlama aşaması ile ilgili son test puan ortalamaları $(4,57)$, kontrol grubu öğrencilerinin puan ortalamalarına $(1,96)$ göre daha yüksektir. Öğrencilerin planlama sürecine ilişkin konuşma düzeyleri deney grubunun lehine, anlamlı bir fark [t(43) $=-8.134, \mathrm{p}<.000]$ göstermektedir. Bilişsel farkındalık stratejilerine dayalı konuşma eğitimi etkinlikleri öğrencilerin konuşmayı planlama düzeylerini, kontrol grubunda uygulanan konuşma eğitimi etkinliklerine göre daha çok geliştirdiği belirlenmiştir.

Tablonun üçüncü satırı incelendiğinde öğrencilerin konuşmayı düzeltme aşaması ile ilgili son test puan ortalamaları deney grubu için 4,54 iken kontrol grubu için 1,69'dur. Öğrencilerin planlama sürecine ilişkin konuşma düzeyleri arasında deney grubunun lehine, anlamlı fark [t(43) =-7.772, $p<.000]$ göstermektedir. Bilişsel farkındalık stratejilerine dayalı konuşma eğitimi etkinlikleri öğrencilerin konuşmayı düzeltme düzeylerini, kontrol grubunda uygulanan konuşma eğitimi etkinliklerine göre daha iyi geliştirdiği belirlenmiştir.

Aynı şekilde, tablonun dördüncü satırı incelendiğinde öğrencilerin konuşmanın sunum aşaması ile ilgili son test puan ortalamaları deney grubu için 4,70 iken kontrol grubu için 2,93'tür. Öğrencilerin sunum sürecine ilişkin konuşma düzeyi son testte puan ortalamaları deney grubunun lehine, anlamlı bir fark [t(43) $=20.570, p<.000]$ göstermektedir. Bilişsel farkındalık stratejilerine dayalı konuşma eğitimi etkinlikleri öğrencilerin konuşmanın sunum aşaması ile ilgili becerilerini, kontrol grubunda uygulanan konuşma eğitimi etkinliklerine göre daha iyi geliştirdiği belirlenmiştir.

Araştırmanın dördüncü alt probleminde, "Deney grubu öğrencilerinin hazırlıklı konuşma ile ilgili bilişsel farkındalık düzeylerine ilişkin ön-son test puanları arasında anlamlı bir fark var mıdır?" sorusuna yanıt aranmıştır.

Bu problemin çözümlenmesinde, deney grubu öğrencilerinin ön-son test hazırlıklı konuşma bilişsel farkındalık ölçeğine verdikleri puanların aritmetik ortalamalarından yararlanılmıştır. Deney grubu öğrencilerinin ön-son test hazırlıklı konuşma bilişsel farkındalık düzeyleri arasında anlamlı bir farkın olup olmadığını test etmek için "ilişkili ölçümler t testi" kullanılmıştır. Bununla ilgili veriler Tablo 10 'da verilmiştir.

Tablo 10. Deney Grubunun Ön-Son Test Hazırlıklı Konuşma Bilişsel Farkındalık Düzeylerine Ait ilişsili Ölçümler $t$ Testi Sonuçları

\begin{tabular}{lllllll}
\hline Grup & $\mathbf{N}$ & $\bar{X}$ & $\mathbf{S}$ & Sd & $\mathbf{T}$ & $\mathbf{P}$ \\
\hline 1. Deney ön test & 22 & 3,05 &, 435 & & &, 000 \\
2. Deney son test & 22 & 4,32 &, 205 & 42 & $-12,398$ & \\
\hline$*$ p $<.5$ anlamlı & & & & &
\end{tabular}

Tablo $10^{\prime}$ da deney grubu öğrencilerinin hazırlıklı konuşma bilişsel farkındalık düzeylerine ait ön-son test puan ortalamaları yer almaktadır. Öğrencilerin hazırlıklı konuşma stratejilerine ilişkin 
bilişsel farkındalık düzeyleri bilişsel farkındalık stratejilerine dayalı hazırlıklı konuşma eğitimi etkinlikleri öncesinde deney grubunun ön test puan ortalamaları 3,05 iken son test puan ortalamaları 4,32'dir. Deney grubu öğrencilerinin hazırlıklı konuşma ile ilgili bilişsel farkındalık düzeylerine ilişkin ön-son test puanları arasında anlamlı bir farkın olup olmadığını belirlemek için öğrencilerin puan ortalamaları, ilişkili ölçümler t testi ile sınanmıştır. Deney grubu öğrencilerinin hazırlıkı konuşma ile ilgili bilişsel farkındalık düzeyleri arasında son test puanları lehine anlamlı bir farkın olduğu [t(42) =-18.393, $p<.000]$ belirlenmiştir. Bu durum, 7. sınıf öğrencilerinin hazırlıklı konuşma düzeylerini artırmaya yönelik yapılan bilişsel farkındalık stratejilerine dayalı hazırlıklı konuşma eğitiminin etkili olduğunu göstermektedir.

Araştırmanın beşinci alt probleminde, "Kontrol grubu öğrencilerinin hazırlıkı konuşma ile ilgili bilişsel farkındalık düzeylerine ilişkin ön-son test puanları arasında anlamlı bir fark var mıdır?" sorusuna yanıt aranmıştır.

Bu problemin çözümlenmesinde, kontrol grubu öğrencilerinin ön-son test Hazırlıklı Konuşma Bilişsel Farkındalık Ölçeğine verdikleri puanların aritmetik ortalamalarından yararlanılmıştır. Kontrol grubu öğrencilerinin ön-son test hazırlıklı konuşma bilişsel farkındalık düzeyleri arasında anlamlı bir farkın olup olmadığını test etmek için "ilişkili ölçümler t testi” kullanılmıştır. Bununla ilgili veriler Tablo $11^{\prime}$ de verilmiştir.

Tablo 11. Kontrol Grubunun Ön-Son Test Hazırıklı Konuşma Bilişsel Farkındalık Düzeylerine Ait ilişkili Ölçümler t Testi Sonuçları

\begin{tabular}{lllllll}
\hline Grup & $\mathbf{N}$ & $\overline{\mathrm{X}}$ & $\mathbf{S}$ & Sd & $\mathbf{T}$ & $\mathbf{P}$ \\
\hline 1. Kontrol ön test & 23 & 3,04 &, 506 & & & \\
2. Kontrol son test & 23 & 3,12 &, 495 & 44 &,- 519 &, $606^{*}$ \\
\hline${ }^{*} \mathrm{p}<, 05$ anlaml & & & & &
\end{tabular}

Tablo $11^{\prime}$ de kontrol grubu öğrencilerinin geleneksel konuşma eğitimi etkinliklerine dayalı hazırlıklı konuşma ile ilgili bilişsel farkındalık düzeyleri puan ortalamaları yer almaktadır. Kontrol grubu öğrencilerinin hazırlıklı konuşma stratejilerine ilişkin bilişsel farkındalık düzeyleri ön test puan ortalamaları 3,04 iken son test puan ortalamaları ise 3,12'dir. Kontrol grubu öğrencilerinin bilişsel farkındalık düzeylerine ilişkin ön-son test puanları arasında anlamlı bir farkın olup olmadığını belirlemek için puan ortalamaları, ilişkili ölçümler $t$ testi ile sınanmıştır. Kontrol grubu öğrencilerinin hazırıklı konuşma ile ilgili bilişsel farkındalık düzeyleri arasında anlamlı bir farkın olmadığı [t(44) = .519, p>.606] belirlenmiştir. Geleneksel konuşma eğitimi etkinliklerine dayalı hazırlıklı konuşma eğitiminin kontrol grubu öğrencilerinin bu konuda edinmeleri gereken bilişsel farkındalığı artırmadığı anlaşıımaktadır. 
Araştırmanın altıncı alt probleminde, "Deney ve kontrol grubu öğrencilerinin hazırlıklı konuşma ile ilgili bilişsel farkındalık düzeylerine ilişkin son test puanları arasında anlamlı bir fark var mıdır?" soruna yanıt aranmıştır.

Bu problemin çözümlenmesinde, kontrol ve deney grubu öğrencilerinin son testte HKBFÖ'ye verdikleri puanların aritmetik ortalamalarından yararlanılmıştır. Deney ve kontrol grubu öğrencilerinin son testteki hazırlıklı konuşma bilişsel farkındalık düzeyleri arasında anlamlı bir farkın olup olmadığını test etmek için “ilişkisiz ölçümler t testi” kullanılmıştır. Bununla ilgili veriler Tablo 12' de verilmiştir.

Tablo 12. Deney ve Kontrol Grubunun Son Test Hazırlıklı Konuşma Bilişsel Farkındalık Düzeylerine Ait Ilişkisiz Ölçümler t Testi Sonuçları

\begin{tabular}{lllllll}
\hline Grup & $\mathbf{N}$ & $\bar{X}$ & $\mathbf{S}$ & Sd & $\mathbf{T}$ & $\mathbf{P}$ \\
\hline 1. Deney son test & 22 & 4,32 &, 205 & & &, 000 \\
2. Kontrol son test & 23 & 3,12 &, 495 & 43 & 10,540 &
\end{tabular}

$* \mathrm{p}<, 05$ anlamlı

Tablo 12 'de deney ve kontrol grubu öğrencilerinin konuşma stratejilerine ilişkin bilişsel farkındalık düzeyleri son test puan ortalamaları yer almaktadır. Deney grubu öğrencilerinin hazırlıklı konuşma stratejilerine ilişkin bilişsel farkındalık düzeyleri son test puanları aritmetik ortalamaları 4,32 iken kontrol grubu öğrencilerinin ise 3,12'dir. Deney ve kontrol grubu öğrencilerinin hazırlıklı konuşma stratejileri ile ilgili bilişsel farkındalık düzeyleri son test puanları arasında deney grubunun lehine anlamlı bir farkın olduğu [t(43) $=10.540, p<.000]$ belirlenmiştir. Bu durum, 7. sınıf öğrencilerinin hazırlıklı konuşma düzeylerini artırmaya yönelik yapılan bilişsel farkındalık stratejilerine dayalı hazırıkı konuşma eğitiminin öğrencilerin hazırlıklı konuşma ile ilgili bilişsel farkındalık düzeylerini geliştirmede daha etkili olduğunu göstermektedir.

Araştırmanın yedinci alt probleminde, "Öğrencilerin bilişsel farkındalık stratejilerine dayalı konuşma etkinlikleriyle ilgili görüşleri nelerdir?" sorusuna yanıt aranmıştır.

Bu bölümde deney grubu öğrencileriyle yapılan görüşmelerden elde edilen bulgu ve yorumlara yer verilecektir. Öğrencilerin $11^{\prime} \mathrm{i}$ kız, $11^{\prime} \mathrm{i}$ ise erkektir. Bu öğrenciler cinsiyetlerine göre $\mathrm{K}$ ve $\mathrm{E}$ harfleriyle ve birer sayıyla kodlanmıştır.

1. Uygulama süreci ile ilgili bulgular: Bu konuşma etkinliklerini yapmadan önceki konuşma durumunuzla şimdiki konuşma durumunuz arasında bir fark hissediyor musunuz?

Öğrencilerin 1'i dışında hepsi bu soruya konuşma etkinlikleri öncesindeki durumlarıyla şimdiki durumları arasında olumlu yönde gelişen bir fark gördükleri şeklinde cevap vermiştir. Öğrencilerin verdikleri cevaplar aşağıdaki tabloda sınıflandırılmıştır. 
Tablo 13. Öğrencilerin "Bu Konuşma Etkinliklerini Yapmadan Önceki Konuşma Durumunuzla Şimdiki Konuşma Durumunuz Arasında Bir Fark Hissediyor Musunuz?" Sorusu Ile Ilgili Görüşleri

\begin{tabular}{llc}
\hline Cevap & Öğrenci Kodu & F \\
\hline \multirow{2}{*}{ Evet } & Ö1K, Ö2K, Ö3K, Ö4E, Ö5E, Ö6K, Ö7E, Ö8K, Ö9E, Ö10K, Ö12K, Ö13E, Ö14K, Ö15E, & 21 \\
\hline Hayır & Ö16E, Ö17K, Ö18E, Ö19K, Ö20E,Ö21K, Ö22E & 1 \\
\hline
\end{tabular}

Tabloda da görüldüğü gibi öğrencilerin $21^{\prime} i$ etkinlikler öncesi konuşma durumlarıyla şimdiki durumları arasında bir fark gördüklerini, 1'i ise herhangi bir fark görmediğini ifade etmiştir. Bu durum bilişsel farkındalık stratejilerine göre düzenlenen konuşma etkinliklerinin öğrencilerin konuşma becerilerini ve kendi konuşmalarına ilişkin farkındalıklarını geliştirdiği şeklinde yorumlanabilir. Öğrencilerin bu soruya verdikleri cevaplardan bazıları aşağıda verilmiştir.

Ö2K: Evet, hissediyorum. Illk konuşmamda kendime olan öz güvenim yoktu. Kendime olan öz güvenimi ikinci konuşmada rahatlıkla belirttim. Bu durumdan da çok memnun oldum. Zaten birinci konuşma ile ikinci konuşma arasında çok büyük fark olduğunu hissettim.

Ö11E: Hayır, bir fark yoktur çünkü eskiden de aynı şeyleri biliyordum. Şimdi de aynı şeyleri biliyorum. Bildiklerimi yaptığım konuşmaya ekledim.

2. Uygulama sürecinin öğrencilere kazandırdıkları ile ilgili bulgular: Hazırlıklı konuşma için yapılan bu uygulamalar size neler kazandırdı? Lütfen belirtiniz.

Görüşmeye katılan öğrencilerden 2'si hariç hepsi bu soruya olumlu şekilde cevap vermişlerdir. Sadece 2 öğrenci bilişsel farkındalık stratejilerine dayalı konuşma etkinliklerinin kendilerine bir şey katmadığını belirtmiştir. Öğrencilerin cevapları temalarına göre aşağıdaki tabloda sınıflandırılmıştır.

Tablo 14. Öğrencilerin "Hazırlıklı Konuşma İçin Yapılan Bu Uygulamalar Size Neler Kazandırdı?” Sorusu Ile IIgili Görüşleri

\begin{tabular}{lll}
\hline Cevap & Öğrenci Kodu & $F$ \\
\hline Kendime güvenim arttı. & Ö2K, Ö6K, Ö9E, Ö12K, Ö14K & 5 \\
\hline Daha iyi konuşuyorum. & Ö7E, Ö10K, Ö20E, Ö21K & 4 \\
\hline Bilgilerimi artırdı. & Ö13E, Ö15E, Ö18E, Ö22E & 4 \\
\hline Göz teması kurmayı öğrendim. & Ö1K, Ö8K & 2 \\
\hline Kendimi ifade etmeyi öğrendim. & Ö4E, Ö11E & 2 \\
\hline Prova yapmanın önemini öğrendim. & Ö3K & 1 \\
\hline Jest mimik kullanmanın önemini öğrendim. & Ö1K & 1 \\
\hline Konunun dışına çımmamayı öğrendim. & Ö4E & 1 \\
\hline Kendimi daha iyi değerlendiriyorum. & Ö5E & 1 \\
\hline Heyecanımı yatıştırabiliyorum. & Ö5E & 1 \\
\hline Davranış ve sözlerime dikkat ediyorum. & Ö1K & 1 \\
\hline Araştırma yapmayı öğrendim. & Ö8K & 1 \\
\hline Daha bilinçli konuşuyorum. & Ö19K & 1 \\
\hline Bana bir şey kazandırmadı. & Ö16E, Ö17K & 2 \\
\hline
\end{tabular}


Tabloda görüldüğü gibi öğrencilerin çoğunluğu olumlu cevaplar vermiştir. Bu cevaplar, verilen eğitimin öğrencilerin konuşma becerilerini geliştirdiği şeklinde yorumlanabilir. Öğrencilerin verdiği cevaplardan bazıları aşağıda verilmiştir.

Ö9E: Bu uygulamalar benim kendime olan güvenimi arttırdı ve rahat konuşma yapmamı sağladı Ö16E: Bana bir şey kazandırdığını düşünmüyorum.

Konuşmalarınızı planlama konusunda bu etkinliklerin size bir yararı oldu mu? Lütfen belirtiniz.

Öğrencilerin 19'u “Konuşmalarınızı planlama konusunda bu etkinliklerin size bir yararı oldu mu?" sorusuna olumlu yönde cevap verirken, öğrencilerin 3'ü etkinliklerin, planlama konusunda bir yararı olmadığı şeklinde cevap vermişlerdir. Öğrenci cevaplarının temalarına göre sınıflandırılması aşağıdaki tabloda verilmiştir.

Tablo 15. Öğrencilerin “Konuşmalarınızı Planlama Konusunda Bu Etkinliklerin Size Bir Yararı Oldu Mu?” Sorusu Ile Ilgili Görüşleri

\begin{tabular}{llc}
\hline Cevap & Ögrenci Kodu & F \\
\hline \multirow{2}{*}{ Evet. } & Ö1K, Ö2K, Ö4E, Ö5E, Ö6K, Ö7E, Ö8K, Ö9E, Ö10K, Ö11E, Ö12K, Ö13E, Ö14K, & 19 \\
\hline Ö15E, Ö16E, Ö17K, Ö19K, Ö20E, Ö22E & 3 \\
\hline
\end{tabular}

Öğrencilerin verdiği cevaplardan bazıları aşağıda verilmiştir.

Ö19K: Evet, çünkü bir daha hazırlıklı konuşma yaptığım zaman daha bilinçli ve planlı şekilde hazırlanabilirim.

Ö21K: Bu konuda fazla yararı olmadı.

Konuşmalarınızı düzeltme konusunda bu etkinliklerin size bir yararı oldu mu? Lütfen belirtiniz.

Öğrenciler, etkinliklerin konuşmalarını düzeltme konusunda kendilerine yararı olup olmadığı sorusuna genelde olumlu cevap vermişlerdir. Konuşmayı düzeltme süreci bilişsel farkındalıkla çok yakından ilgili olduğu için bu soruya verilen cevapların olumlu olması, yapılan etkinliklerin, öğrencilerin bilişsel farkındalık düzeylerini artırmada faydalı olduğu söylenebilir.

Tablo 16. Öğrencilerin "Konuşmalarınızı Düzeltme Konusunda Bu Etkinliklerin Size Bir Yararı Oldu Mu?” Sorusu Ile ilgili Görüşleri

\begin{tabular}{llc}
\hline Cevap & Öğrenci Kodu & F \\
\hline \multirow{2}{*}{ Evet. } & Ö2K, Ö3K, Ö4E, Ö5E, Ö7E, Ö8K, Ö9E, Ö12K, Ö13E, Ö14K, Ö15E, Ö16E, Ö17K, & 18 \\
\hline Ö18E, Ö19K, Ö20E, Ö21K, Ö22E & 4 \\
\hline
\end{tabular}

Tabloya göre öğrencilerin $18^{\prime} \mathrm{i}$ etkinliklerin konuşmalarını düzeltme konusunda kendilerine bir yararı olduğunu, 4'ü ise etkinliklerin bu konuda kendilerine bir yarar sağlamadığını ifade etmiştir. Cevapların çoğunlukla olumlu olması yapılan etkinliklerin öğrenciler üzerinde bir etkisinin ve yararının olduğu şeklinde yorumlanmalıdır. Öğrencilerin verdiği cevaplardan bazıları aşağıda verilmiştir. 
Ö18E: Evet oldu, çünkü eskiden konuşmalarımda hatalarım olurdu, ama etkinlik yapa yapa hatalarım azaldı.

Ö6K: Hayır, olmadı.

Konuşmalarınızı sunarken bu etkinlikler size öz güven sağladı mı? Lütfen belirtiniz.

Öğrencilerin, etkinliklerin, kendilerine bir öz güven sağlayıp sağlamadığına ilişkin soruya verdikleri cevaplara bakıldığında bilişsel farkındalık stratejilerine dayalı konuşma etkinliklerinin genel olarak öğrencilerin öz güvenlerini artırdığı görülmektedir.

Tablo 17. Öğrencilerin "Konuşmalarınızı Sunarken Bu Etkinlikler Size Öz Güven Sağladı Mı?” Sorusu Ile IIgili Görüşleri

\begin{tabular}{llc}
\hline Cevap & Öğrenci Kodu & F \\
\hline \multirow{2}{*}{ Evet. } & Ö1K, Ö2K, Ö4E, Ö5E, Ö6K, Ö7E, Ö8K, Ö9E, Ö10K, Ö12K, Ö13E, Ö14K, Ö15E, Ö16E, & 20 \\
\hline Ö17K, Ö18E, Ö19K, Ö20E, Ö21K, Ö22E & 2 \\
\hline
\end{tabular}

Tabloya bakıldığında 20 öğrencinin bilişsel farkındalık stratejilerine dayalı konuşma etkinliklerinin öz güvenlerini artırdığını, 2 öğrencinin ise öz güvenlerinde bir değişiklik olmadığını ifade ettikleri görülmektedir. Cevapların çoğunluğunun olumlu yönde olması verilen eğitimin öğrencilerin konuşma sırasındaki öz güvenlerini artırmada bir etken olduğu şeklinde yorumlanmalıdır. Öğrencilerin bu soruya verdikleri cevaplardan bazıları aşağıda verilmiştir.

Ö2K: Sınıfta çok utangaçtım bu çalışmayla kendime olan güvenim arttı. Kendimi rahat hissettim. Insanlarla olan diyalogum gelişti.

Ö11E: Hayır sağlamadı.

Öğrencilerin sorulara vermiş olduğu cevaplar genel olarak bilişsel farkındalık stratejilerine dayalı konuşma etkinliklerinin öğrencilerin konuşma becerilerini planlama, düzeltme ve sunma aşamalarındaki başarılarına, öz güvenlerine olumlu yönde etki ettiğini göstermektedir. Öğrencilerin verdikleri cevaplarda konuşma sürecinin farklı aşamalarında geliştiklerini ve daha rahat konuştuklarını ifade etmeleri, ayrıca bu etkinliklerin kendilerine birçok açıdan yarar sağladığını söylemeleri, bu görüşe bir kanıt olarak yorumlanabilir.

\section{Tartışma, Sonuç ve Öneriler}

Bilişsel farkındalık stratejilerine dayalı konuşma eğitimi etkinliklerinin uygulandığı deney grubundaki öğrencilerin ön-son test hazırlıklı konuşma düzeyleri aritmetik ortalamaları arasında anlamlı farklılık bulunmuştur. Bu sonuç, 7. sınıf öğrencilerinin hazırlıklı konuşma düzeylerini artırmaya yönelik yapılan bilişsel farkındalık stratejilerine dayalı konuşma eğitimi etkinliklerinin hazırlıklı konuşma becerisini geliştirdiğini göstermektedir. Alanyazındaki strateji eğitimi üzerine yapılan araştırmalar da verilen strateji eğitiminin öğrencilerin stratejileri kavrama becerilerini olumlu yönde etkilediğini ortaya 
koymaktadır. Nakatani'nin (2005) yapmış olduğu çalışmada strateji eğitimi alan öğrencilerin, strateji eğitimi almayan öğrencilere göre konuşma sınavlarında daha başarılı oldukları tespit edilmiştir. Koşar ve Bedir'in (2014) yapmış oldukları çalışmada da konuşma stratejilerinin bilinçli olarak kullanılmasının konuşma becerisini geliştirmede etkili olduğu görülmüştür. Atik'in (2006) yapmış olduğu çalışmada strateji eğitimi alan ortaöğretim öğrencilerinin, strateji kullanma düzeylerinin ilerlediği tespit edilmiştir. Forbes ve Fisher (2018)'in yaptığı çalışmada da öğrencilerin strateji kullanımının ve bu stratejilerle ilgili farkındalıklarının arttııımasının, öğrencilerin konuşma yeterliliklerini olumlu şekilde etkilediği belirlenmiştir. Bu sonuçlar, strateji eğitimi alan öğrencilerin konuşma becerilerinin gelişmesi yönüyle araştırma sonuçlarını desteklemektedir.

Ayrıca bilişsel farkındalık stratejilerine dayalı konuşma eğitimi etkinliklerinin uygulandığı deney grubu öğrencilerinin; hazırlıklı konuşmanın hazırlık, planlama, düzeltme ve sunum süreçleri ile ilgili puan ortalamaları arasında anlamlı bir farklılık bulunmuştur. Deney grubu öğrencilerine verilen eğitimin, öğrencilerin hazırlıklı konuşmanın hazırlık, planlama, düzeltme ve sunum aşamasındaki becerilerini geliştirdiği tespit edilmiştir. Yıldız (2014)'ın üniversite öğrencileri üzerine yaptığı araştırmada da strateji eğitimi alan öğrencilerin sunum yapma becerilerinin geliştiği belirlenmiştir.

Geleneksel eğitim anlayışıyla işlenen Türkçe derslerindeki konuşma etkinlikleri, kontrol grubu öğrencilerinin hazırlıklı konuşmalarında anlamlı bir farklılık oluşturmamıştır. Bu durum, 7. sınıf öğrencilerinin hazırlıklı konuşma düzeylerini artırmaya yönelik yapılan geleneksel konuşma eğitimi etkinliklerinin hazırlıklı konuşma becerisini geliştirmediğini göstermektedir. Zira kontrol grubu öğrencilerinin konuşmanın hazırlık aşaması ile ilgili puan ortalamalarına bakıldığında, geleneksel konuşma eğitimi etkinliklerinin öğrencilerin konuşmaya hazırlık yapma düzeylerini geliştirmediği hatta anlamlı bir şekilde gerilettiği görülmektedir. Ayrıca konuşmanın planlama, düzeltme ve sunum aşamaları ile ilgili ön-son test puan ortalamaları arasında anlamlı bir farklılık bulunmamıştır. Bu sonuç, geleneksel konuşma eğitimi etkinliklerinin öğrencilerin konuşmayı planlama, düzeltme ve sunum aşamaları ile ilgili becerilerini geliştirmediğini göstermektedir.

Deney grubu ve kontrol grubu öğrencilerinin son test hazırlıkı konuşma puan ortalamaları arasında, bilişsel farkındalık stratejilerine dayalı konuşma eğitimi etkinliklerinin uygulandığı deney grubunun lehine anlamlı bir farkın olduğu tespit edilmiştir. Bu sonuç, yapılan etkinliklerin deney grubu öğrencilerinin hazırlıklı konuşma becerisini, kontrol grubuna göre daha iyi ve anlamlı fark yaratacak derecede geliştirdiğini göstermektedir. Ayrıca hazırlıkı konuşmanın aşamaları olan hazırlık, planlama, düzeltme ve sunum süreci ile ilgili deney ve kontrol grubu son test puan ortalamaları, deney grubunun lehine anlamlı bir fark göstermektedir. Bu durum, deney grubunda uygulanan bilişsel farkındalık stratejilerine dayalı konuşma eğitimi etkinliklerinin, öğrencilerin konuşmanın hazırlık, planlama, 
düzeltme ve sunum aşamaları ile ilgili becerilerini, kontrol grubunda uygulanan geleneksel konuşma eğitimi etkinliklerine göre daha iyi geliştirdiği belirlenmiştir.

Bilişsel farkındalık stratejilerine dayalı uygulanan eğitimin değerlendirilmesi ve öğrenciler üzerindeki etkisini belirlemek amacıyla öğrencilerle yapılan görüşme sonucunda, yapılan etkinliklerin öğrenciler açısından konuşmanın hazırlanması, planlanması, düzeltilmesi ve sunulması hususlarında yararlı olduğu ve özgüven oluşturması açısından da faydalı olduğu belirlenmiştir. Öğrencilerin konuşma kaygılarının azaldığına ve özgüven kazandıklarına dair elde edilen bu sonuçlar, bilişsel farkındalık stratejilerine göre düzenlenen konuşma etkinliklerinin öğrencilerin konuşma becerilerini ve kendi konuşmalarına ilişkin farkındalıklarını, süreci yönetme açısından özdenetim geliştirdiğini göstermektedir. Ayrıca bu sonuçlar; Özdemir (2018) ile Forbes ve Fisher (2018)'in araştırma bulguları ile de örtüşmektedir.

Bu araştırmadan elde edilen veriler, geleneksel konuşma eğitimi etkinliklerinin yeterliliği hakkında kaygı uyandırmaktadır. Çünkü okullarımızda uygulanan konuşma etkinlikleri sadece öğrencinin çeşitli aşamalarda gösterdiği performans üzerine kurulmuştur. Sözgelimi öğretmen sadece öğrenciye konuşma konusu verip onu konuşturmakla konuşma becerisinin gelişeceğini düşünmektedir. Bunun yanında programda önerilen etkinlikler de öğrencinin konuşma becerisini geliştirmeye yönelik olsa da doğrudan doğruya öğrencinin kendi konuşma performansı üzerinde düşünmesine yani kendi konuşması konusunda bir bilişsel farkındalık geliştirmesine yönelik değildir. Bu konuda öğretmenlerin yetersiz olması ihtimali de öğrencilerin özdenetim edinmelerini etkiler. Öğrencilerin bir konuşma etkinliğinde sadece yaptıkları hata ve doğruları bilmeleri yeterli değildir. Fakat aynı zamanda bu sürecin tamamını nasıl yürüteceklerini bilmeleri ve buna uygun her aşamada uygun stratejileri kullanabilmeyi öğretmek önemlidir. Aksi hâlde sadece doğru ve yanlışları gören fakat belki de bunun nedenleri üzerinde düşünmeyen ve konuşma başarısı düştüğünde bununla nasıl baş edeceğini, başarısını nasıl yükselteceğini bilmeyen öğrenciler yetiştirilmiş olacaktır.

Araştırmanın sonuçları kapsamında şu önerilerde bulunulmuştur:

1. Yapılan çalışmada bilişsel farkındalık stratejilerinin öğrencilerin konuşma becerilerini geliştirdiği görülmüştür. Bundan hareketle öğrencilere uygulanacak konuşma etkinlikleri, bilişsel farkındalık stratejilerine uygun olarak hazırlanabilir.

2. Bilişsel farkındalık stratejileriyle konuşma becerisinin geliştirilmesine yönelik yedinci sınıf öğrencileriyle yapılan bu çalışma, diğer sınıflarda da yapılabilir.

3. Farklı sınıf düzeylerinde yürütülecek olan çalışmalarda bilişsel farkındalık stratejilerine dayalı konuşma eğitiminin diğer dil becerilerine etkileri araştırılabilir. 
4. Bilişsel farkındalık stratejilerine dayalı konuşma eğitiminin akademik başarıya etkisi araştırılabilir.

\section{Kaynaklar}

Akkaya, A. (2012). Öğretmen adaylarının konuşma sorunlarına ilişkin görüşleri. Mustafa Kemal Üniversitesi Sosyal Bilimler Enstitüsü Dergisi.9(20), 405-420.

Arıkan, M. (2004). Nitelikli Insan. İstanbul: Bilge Yayıncılık.

Arslan, A. ( 2012). Üniversite öğrencilerinin “topluluk karşısında konuşma” ile ilgili çeşitli görüşleri (Ağrı İbrahim Çeçen Üniversitesi Örneği). Turkish Studies- International Periodical For The Languages, Literature and History of Turkish or Turkic, 7(3), 221-231.

Atik, B B. (2006). The effect of strategies-based instruction on speaking skills of high school students. Yüksek Lisans Tezi. Çukurova Üniversitesi Sosyal Bilimler Enstitüsü Adana.

Aydın, N. ve Yılmaz, A. (2010). Yapılandırmacı yaklaşımın öğrencilerin üst düzey bilişsel becerilerine etkisi. Hacettepe Üniversitesi Eğitim Fakültesi Dergisi. 39, 57-68.

Ayres, L. (2008). Semi-structured interview. In L. M. Given (Ed.) The SAGE encyclopedia of qualitative research methods, (pp. 810-811). SAGE Publication.

Bağçeci, B., Döş, B. ve Sarıca, R. (2011). İlköğretim öğrencilerinin üstbilişsel farkındalık düzeyleri ile akademik başarısı arasındaki ilişkinin incelenmesi. Mustafa Kemal Üniversitesi Sosyal Bilimler Enstitüsü Dergisi,8(16), 551-566.

Candan, A. S. (2005). Üstbilişsel kuram ve tarih öğretimi. Kastamonu Eğitim Dergisi,13(2),327-332.

Chamot, A. U. (1987). The learning strategies of ESL students. Wenden, A., Rubin, J. (ed.), Learning strategies in language learning (s. 71-83), New York: Prentice Hall.

Demir, Ö. (2009). Bilişsel koçluk yöntemiyle öğretilen bilişsel farkındalık stratejilerinin altıncı sınıf sosyal bilgiler dersinde öğrencilerin epistemolojik inançlarına, bilişsel farkındalık becerilerine, akademik başarılarına ve bunların kalıcılıklarına etkisi. Doktora Tezi. Çukurova Üniversitesi Sosyal Bilimler Enstitüsü, Adana.

Doğan, Y. (2009). Konuşma becerisinin geliştirilmesine yönelik etkinlik önerileri. Türk Eğitim Bilimleri Dergisi. 7 (1),185-128.

Eggen, Paul-Don Kauchak (2001) Educationa IPsychology, New Jersey, USA

Flavell, J. H. (1979). Metacognition and cognitive monitoring: A new area of cognitive developmental inquiry. American Psychologist, 34, 906-911.

Forbes, K. ve Fisher, L. (2018) The impact of expanding advanced level secondary school students' awareness and use of metacognitive learning strategies on confidence and proficiency in foreign language speaking skills, The Language Learning Journal, 46:2, 173-185,

Göçer, A. (2008). Performans görevi ile ilgili sunum çalışmalarının konuşma ve dinleme becerilerinin geliştirilmesine katkısı. Dil Dergisi.137(8), 7-17.

Güneş, F. (2014). Türkçe öğretimi yaklaşımlar ve modeller. Ankara: Pegem Akademi.

Karakoç Öztürk, B. ve Altuntaş, i. (2012). Illköğretim ikinci kademede konuşma eğitimine yönelik öğretmen görüşleri: Nitel bir çalışma. Eğitim ve Öğretim Araştırmaları Dergisi. Journal of Research in EducationandTeaching.1(2), 342-356.

Karasar, N. (2008). Bilimsel araștırma yöntemi. Ankara: Nobel.

Karatay, H. (2009). Okuma stratejileri bilişsel farkındalık ölçeği. Abant Izzet Baysal Üniversitesi Sosyal Bilimler Enstitüsü Dergisi.2(19), 58-78.

Karatay, H. (2010). İlköğretim öğrencilerinin okuduğunu anlama ile ilgili bilişsel farkındalıkları. Türklük Bilimi Araştırmaları, 27, 457-475. 
Kaya, A. (2011). Etkili ve güzel konuşma sanatı. Konya: Eğitim Kitabevi.

Koşar, G. ve Bedir, H. (2014). Strategies based instruction: a means of improving adult elf learners speaking skills. International Journal of Language Academy.2(3). 12-26.

Melanlıoğlu, D. (2011).Üstbiliş stratejileri eğitiminin ilköğretim ikinci kademe öğrencilerinin dinleme becerilerine etkisi. Doktora Tezi, Gazi Üniversitesi Eğitim Bilimleri Enstitüsü, Ankara.

Nakatani, Y. (2005). The effects of awareness-raising training on oral communication strategy use. The Modern Language Journal, 89, 76-91.

Namlu, A. G. (2004). Bilişötesi öğrenme stratejileri ölçme aracının geliştirilmesi: geçerlilik ve güvenirlik çalışması. Anadolu Üniversitesi Sosyal Bilimler Dergisi, 4(2), 123-141.

O'Malley, M. ve Chamot, U. (1990). Learning strategies in second language acquisition. Cambridge: Cambridge University Press.

Oxford, R. L. (1990). Language learning strategies: What every teacher should know. Boston: Heinle\&Heinle.

Özdemir, E. (1999). Güzel ve etkili konuşma sanatı. İstanbul: Remzi.

Özdemir, S. (2018). Türkçe Öğretmeni Adaylarının Konuşma Kaygısını Gidermede Hazırıklı Konuşmaların Rolü. Abant Izzet Baysal Üniversitesi Eğitim Fakültesi Dergisi, 18 (1), 361-374.

Razmjoo, S.A., ve Arkedani, S. G.(2011). A model of speaking strategies for efl learners. The Journal of Teaching Language Skills.3(3), 116-142. 3 Mart 2015 tarihinde http://jtls.shirazu.ac.ir/article_380_58.html sayfasından erişilmiştir.

Sargın, M. (2006). Illköğretim öğrencilerinin konuşma becerilerinin değerlendirilmesi Muğla ili örneğinde. Yüksek Lisans Tezi. Muğla Üniversitesi, Sosyal Bilimler Enstitüsü, Muğla.

Schraw, G. ve Dennison, R.S. (1994). "Assessing Metacognitive Awareness". Contemporary Educational Psychology, 19, 460-475

Taşer, S. (2012). Konuşma eğitimi, İstanbul: Pegasus.

Temizyürek, F. (2007). İlköğretim ikinci kademede konuşma becerisinin geliştirilmesi. Ankara Üniversitesi Eğitim Bilimleri Fakültesi Dergisi, 40(2), 113-131.

Temizyürek, F., Erdem, i., ve Temizkan, M. (2011). Konuşma eğitimi. Ankara: Pegem Akademi.

Topçuoğlu F. ve Özden, D. (2011). Diksiyon ve konuşma eğitimi. Ankara: Pegem Akademi.

Topçuoğlu Ünal, F. ve Degeç, H. (2012). Öğretmen görüşlerine göre konuşma eğitiminde karşılaşılan sorunlar. The Journal of Academic Social Science Studies, 5(7),735-750.

Topuzkanamış, E. (2014). Yazma stratejileri öğretiminin Türkçe öğretmenliği birinci sınıf öğrencilerinin yazılı anlatıma başarısı ve yazma kaygısına etkisi. Doktora Tezi. Gazi Üniversitesi Eğitim Bilimleri Enstitüsü, Ankara.

Xu, W. (2012). A survey on metacognitive strategy use in college oral English study under internet environment with a case study of Guilin University of Technology. Theory and practice language studies, 2(7), 14301435.

Yalçın, A. (2002). Türkçe öğretim yöntemleri yeni yaklaşımlar. Ankara: Akçağ.

Yelok, V. ve Sallabaş, M. E. (2009). Öğretmen adaylarının sözlü anlatım dersine ve sözlü anlatıma yönelik tutumlarının değerlendirilmesi, Türk Eğitim Bilimleri Dergisi, 7 (3), 581-606.

\section{Extended Abstract}

Introduction

Speaking ability which is a distinguishing feature of humans and makes them superior to other creatures is an innate skill of humans. Speaking being one of the four language skills is used the most after speaking and listening skills (Temizyürek, Erdem and Temizkan, 2011, s. 200). We make use of speaking skill in every second of 
our occupational, educational and social life. Teaching speaking being so important for human life should be executed with extreme caution.

There are two kinds of speaking; prepared and unprepared. Unprepared speaking is applied without planning what, why and to what extent to speak, and it is used the most in a daily life.

Prepared speaking has more potential to effect, direct and evoke the audience compared to unprepared speaking. It is more advantageous than unprepared speaking in terms of planning and preparation, rehearsing the speech for several times and revisin it and making corrections on it accordingly.

Not planning the speech beforehand in mind systematically may cause difficult situations for speakers. It is so important to know where, how and when to use the information. It is related to individual's awareness of his own thinking process because successful learners are responsible for and take an active part in their own learning process.

Awareness of individuals' self learning process is related to cognitive awareness. A speaker with cognitive awareness plans his/her speech beforehand, controls whether his/her message is clear enough and arranges his/her words accordingly. He also controls whether he is achieving aims that he determined for the topic of his speech and whether he is meeting the expectations.

Two focuses of this study are as follows. Strategies of cognitive awareness will develop learners' speaking skills and will cause to develop awareness in terms of the improvement of their own speaking ability. The $7^{\text {th }}$ grade students were chosen as a study group for the study. Moreover, although cognitive awareness strategies have been the focus of many studies in this field, they have not been evaluated in terms of speaking strategies. Significance of this research is to be the first in literature.

Method

A mixed method which consists of both qualitative and quantitative methods was used in the study. Interview was used for qualitative part of the research. In the quantitative part, to determine the effects of cognitive awareness strategies on speaking skill, pre-test post-test experimental were used. The research was applied to the $7^{\text {th }}$ grade students studying at 50. YIl Secondary School. The experimental group consisted of 11 female and 11 male students, 22 participants in total, and control group consisted of 12 female and 11 male students, 23 participants in total. In the research, "The Scale of Speaking Strategies Cognitive Awareness Scale" developed by the researcher, "Assessment Scale for the Prepared Speaking", "Self-assessment Scale for the Prepared Speaking" and an "Interview Form" including open-ended questions were used to collect data. Speaking activities were carried in line with cognitive awareness strategies for 12 weeks in the experimental group. In the control group, activities were carried by following the traditional course book.

\section{Result and Discussion}

A meaningful difference on speaking levels was determined between in arithmetic average of pre-test post-test in experimental group in which activities were based on cognitive awareness strategies. This finding proves that applying speaking activities which are designed by using cognitive awareness strategies improves prepared speaking skills of the $7^{\text {th }}$ grade students' prepared speaking skills. In the study of Nakatani (2005) it was determined that the students who had strategy education were more successful in speaking exams than the students who didn't. It was also stated in the study by Koşar and Bedir (2014) that conscious use of the strategies of speaking was effective in improving speaking skill. These results support the findings of this study in that having trained on strategies as a student regarding the speaking skills effect the improvement of this skill positively.

The Turkish lessons taught by following a traditional way did not create a meaningful difference in the prepared skills of the control group students. This finding shows that traditional speaking activities do not improve prepared speaking skills of the $7^{\text {th }}$ grade students.

After the interviews were executed with the aim of determining the effect of education based on cognitive awareness strategies, it was found out that the activities were useful for students in terms of preparing, planning, revising and presenting the speech, and they were also useful for gaining self confidence. 